\title{
Geophysical assessment and hydrocarbon potential of the Cenomanian Bahariya reservoir in the Abu Gharadig Field, Western Desert, Egypt
}

\author{
Mohammad Abdelfattah Sarhan ${ }^{1}$ (D)
}

Received: 4 July 2021 / Accepted: 31 August 2021 / Published online: 15 September 2021

(C) The Author(s) 2021

\begin{abstract}
In this study, the sandstones of the Bahariya Formation in the Abu Gharadig Field, which is a promising oil reservoir in the Abu Gharadig Basin, Western Desert, Egypt, were assessed. The wireline logs from three wells (Abu Gharadig-2, Abu Gharadig-6, and Abu Gharadig-15) were studied using seismic and petrophysical analyses. Based on seismic data, the study area contains an ENE-WSW anticlinal structure, which is divided by a set of NW-SE normal faults, reflecting the effect of Late Cretaceous dextral wrench tectonics on the northern Western Desert. The visual analysis of the well logs reveals a potential zone within well Abu Gharadig-2 located between depths of 10,551 and 10,568 ft (zone A). In contrast, potential zones were detected between depths of 11,593-11,623 ft (zone B) and 11,652-11,673 ft (zone C) in well Abu Gharadig-6. In well Abu Gharadig-15, potential zones are located between depths of 11,244-11251ft (zone D) and 11,459-11,467 ft (zone E). The quantitative evaluation shows that the intervals B and C in well AG-6 are the zones with the highest oil-bearing potential in the Abu Gharadig Field in terms of the reservoir quality. They exhibit the lowest shale volume (0.06-0.09), highest effective porosity (0.13), minimum water saturation $(0.11-0.16)$, lowest bulk volume of water $(0.01-0.02)$, high absolute permeability $(10.92-13.93 \mathrm{mD})$, high relative oil permeability $(\sim 1.0)$, and low water cut $(\sim 0)$. The apex of the mapped fold represents that the topmost Bahariya Formation in the Abu Gharadig Field for which the drilling of additional wells close to well AG-6 is highly recommended.
\end{abstract}

Keywords Abu Gharadig Basin $\cdot$ Bahariya Formation $\cdot$ Seismic interpretation $\cdot$ Well logging evaluation

\section{Introduction}

The Abu Gharadig Basin is the most significant and largest oil-producing basin in the northern Western Desert of Egypt (Fig. 1a). Numerous geological and geophysical studies have been performed in the Abu Gharadig sedimentary basin (e.g., Labib 1985; Bayoumi and Lotfy 1989; Abd El Aal 1988; Awad 1984; El Sayed et al. 1993; Khaled 1999; El Diasty and Moldowan 2012; Nabawy and ElHariri 2008; El Gazzar et al. 2016; Sarhan and Collier 2018; Sarhan 2017a,b,c; Elmahdy et al. 2020; Sarhan 2020).

Hydrocarbons are frequently extracted from structural traps in the Abu Gharadig Basin and other basins in the

Mohammad Abdelfattah Sarhan

msarhan@du.edu.eg

1 Geology Department, Faculty of Science, Damietta University, New Damietta City 34517, Egypt
Western Desert, which are related to Syrian arc tectonics (Moustafa 2008; Dolson et al. 2001; Abu El Naga 1984). These traps exhibit three- or four-way closures in addition to fault block structures, particularly NW-SE- and NE-SWtrending faults (Abd El Aal 1988; Sultan and Abd El Halim 1988).

Jurassic and Cretaceous deposits are the essential source rocks of petroleum in the Abu Gharadig Basin (Shahin 1992). However, the sandstone beds of the Bahariya Formation are the utmost hydrocarbon reservoirs in most sedimentary basins of the Western Desert (e.g., Sarhan et al. 2017), particularly in the Abu Gharadig Basin (EGPC 1992; Sestini 1995). The Bahariya and Abu Roash formations contain more than $90 \%$ of the recognized hydrocarbon reserves in the Western Desert (Richardson et al. 1998).

The study area of this work is the Abu Gharadig Field, which is in the middle of the Abu Gharadig Basin between $28.3^{\circ}$ and $28.5^{\circ} \mathrm{E}$ and $29.5^{\circ}$ and $29.7^{\circ} \mathrm{N}$ (Fig. 1a). The aim of this study was to determine the hydrocarbon potential 
Fig. 1 a Map showing different basins in the Western Desert and the location of the Abu Gharadig Field (simplified from Bosworth et al. 2008); b seismic lines and location of the examined wells within the Abu Gharadig Field
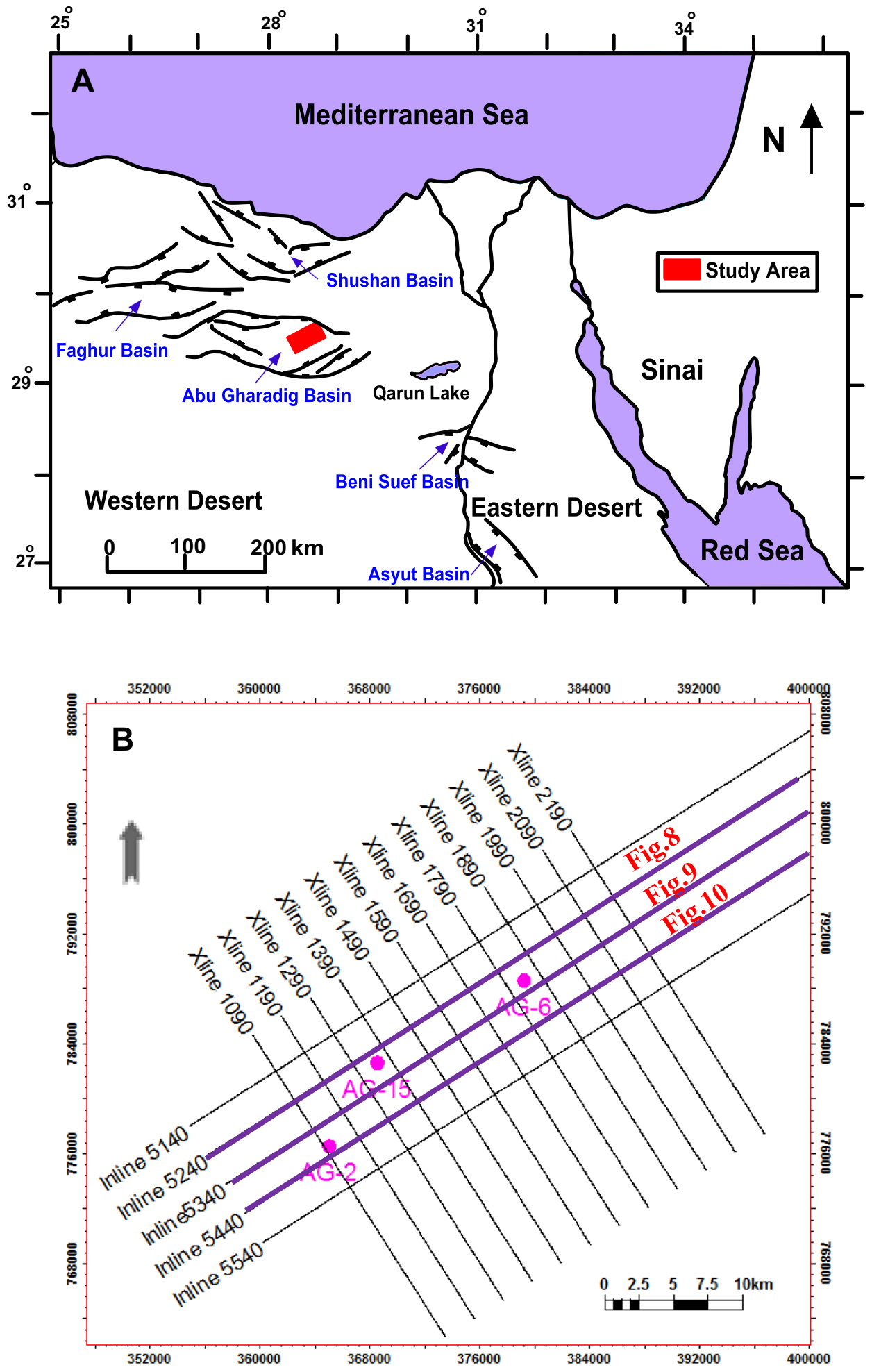

of Bahariya sandstones in the Abu Gharadig Field based on the integration of seismic and well-log data from three wells, that is, Abu Gharadig-2, Abu Gharadig-6, and Abu
Gharadig-15. The objectives include the seismic mapping and petrophysical assessment of the entire sandstone layers of the Bahariya Formation in these wells. 


\section{Geologic setting}

The Abu Gharadig Basin is part of the "Unstable Shelf" area in Egypt (Said 1990). Its rift was initiated in the Jurassic-Early Cretaceous. It comprises a thick sedimentary sequence ranging in age from Jurassic to Tertiary. This basin was affected by dextral wrench tectonics until the Late Cretaceous (e.g., Sarhan 2017b), which were due to the westward movement of the African Plate compared with the Laurasian Plate based on the faster opening of the northern Atlantic Ocean compared with its central part (Smith 1971; Biju-Duval et al. 1977).

However, in the Santonian, the movement of the African Plate shifted into the northern direction, which led to large-scale inversion tectonics affecting the subsurface sedimentary sections in the northern Western Desert (Guiraud and Bosworth 1997). This inversion affected the Abu Gharadig Basin until the Early Tertiary (Moustafa 2008). The inversion phase influenced the former normal faults in the Abu Gharadig Basin (Moustafa 2008; Lüning et al. 2004; Bayoumi and Lotfy 1989) and a series of NE-SW-trending folds formed, that is, the Syrian arc fold system (e.g., Moustafa and Khalil 1990; Ayyad and Darwish 1996; Moustafa et al. 1998; Moustafa 2002).

The inversion tectonics were associated with a large uplift phase and led to the erosion of Upper Cretaceous strata in the extremely inverted zone, whereas deeply buried anticlines in the south of this zone did not breach but entrapped the hydrocarbons (Moustafa 2008).

The Bahariya Formation has attracted the attention of numerous geologic researchers (e.g., Afify et al. 2015; Ela et al. 2018; Abdelwahhab and Raef 2020; Mansour et al. 2020; Farrag et al. 2021; Wanas and Assal 2021). It represents the Cenomanian age (Fig. 2) and was deposited under near-shore to shallow marine environment in the beginning of the Late Cretaceous transgression in the Western Desert (Said 1990; El Ayouty 1990; Wahdan et al. 1996). It contains several sedimentary facies including barrier bars, distributary channels, point bars, and mouth bars (El Sayed et al. 1993).

\section{Data and techniques}

Seventeen seismic SEGY profiles in time unit within the Abu Gharadig Basin were examined and interpreted. These seismic sections were tied to three wells (Fig. 1b): Abu Gharadig-2 (AG-2), Abu Gharadig-6 (AG-6), and Abu Gharadig-15 (AG-15). The seismic data comprise twelve NNW-SSE crosslines with a length of $25 \mathrm{~km}$, and five
ENE-WSW inline sections extend over $55 \mathrm{~km}$. Digital seismic data were interpreted, and a structure map was constructed using Petrel Software (version 2009.1).

Conventional wireline logs from the three examined wells were analyzed using Techlog software (version 2011.1.0). These data consist of: Caliper (CALI), Bit Size, Density Correction (DRHO), Gamma Ray (GR), Sonic (DT), Shallow Resistivity (RS), Deep Resistivity (RD), Medium Resistivity (RM), Density (RHOB), and Neutron (NPHI) logs, as shown in Figs. (3, 4, 5, 6 and 7). The formation logs for wells AG-2, AG-6, and AG-15 and the composite log for well AG-6 were used in the present study. Also, the check-shot data for the examined wells are available to perform the seismic-well tying.

First, the seismic horizon corresponding to the topmost Bahariya Formation was selected, which is next to the fault segments over the seismic line grid (Figs. 8, 9 and 10). The selected horizon and associated faults were mapped (Fig. 11) and then converted from time into depth units (Fig. 12). The mapped structures were analyzed in terms of the tectonic setting of the Abu Gharadig Basin during the Late Cretaceous.

Subsequently, the digital logs of the wells were qualitatively and quantitatively analyzed. This step is important because it involves the detection of potential hydrocarbon-bearing zones within the Bahariya Formation. The results indicate a potential zone in well AG-2 between depths of 10,551 ft and 10,568 ft (zone A). Potential zones in well AG-6 occur between depths of 11,593-11,623 ft (zone B) and 11,652-11,673 ft (zone C). In contrast, in well AG-15, potential zones were discovered at depths of 11,244-11251ft (zone D) and 11,459-11,467 ft (zone E).

The qualitative criteria used for the identification of the five zones include: high resistivity, confirming the occurrence of non-conductive oil; low gamma radiation, indicating the purity of the examined sandstone (i.e., low shale content); and deflection of the neutron log and density curve to the right and left, respectively, forming a crossover feature that characterizes the sandstone matrix.

The wireline logs of the potential zones (A, B, C, D, and $\mathrm{E}$ ) were quantified. The fundamental petrophysical parameters were calculated, which is mandatory for assessing the potentials of hydrocarbon reservoirs. The following parameters were calculated: shale volume, total porosity, effective porosity, water saturation, bulk volume of water (BVW), absolute permeability, and irreducible water saturation. The results are displayed in Tables 1 , 2, 3, 4, and 5 for zones A, B, C, D, and E, respectively. The applied cutoff values for the examined parameters in this study are: shale volume $<30 \%$, porosity $>10 \%$, water saturation $<50 \%$, BVW $<0.05$, and permeability $>0.1 \mathrm{mD}$.

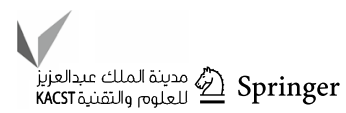




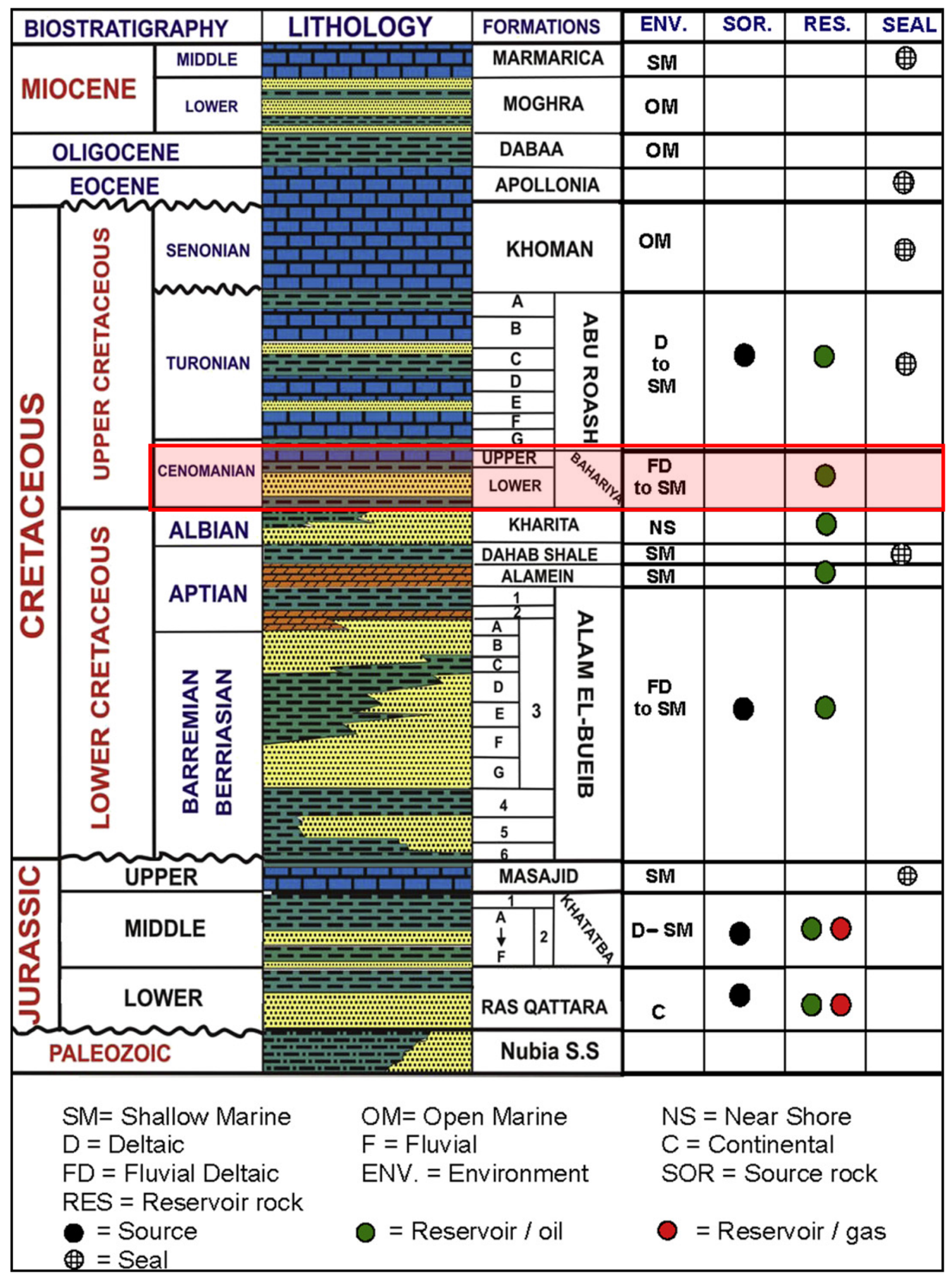

Fig. 2 Regional stratigraphic column of the northern part of the Egyptian Western Desert comprising Abu Gharadig Basin (modified by Shalaby et al. 2011 after; Schlumberger 1984, 1995) 


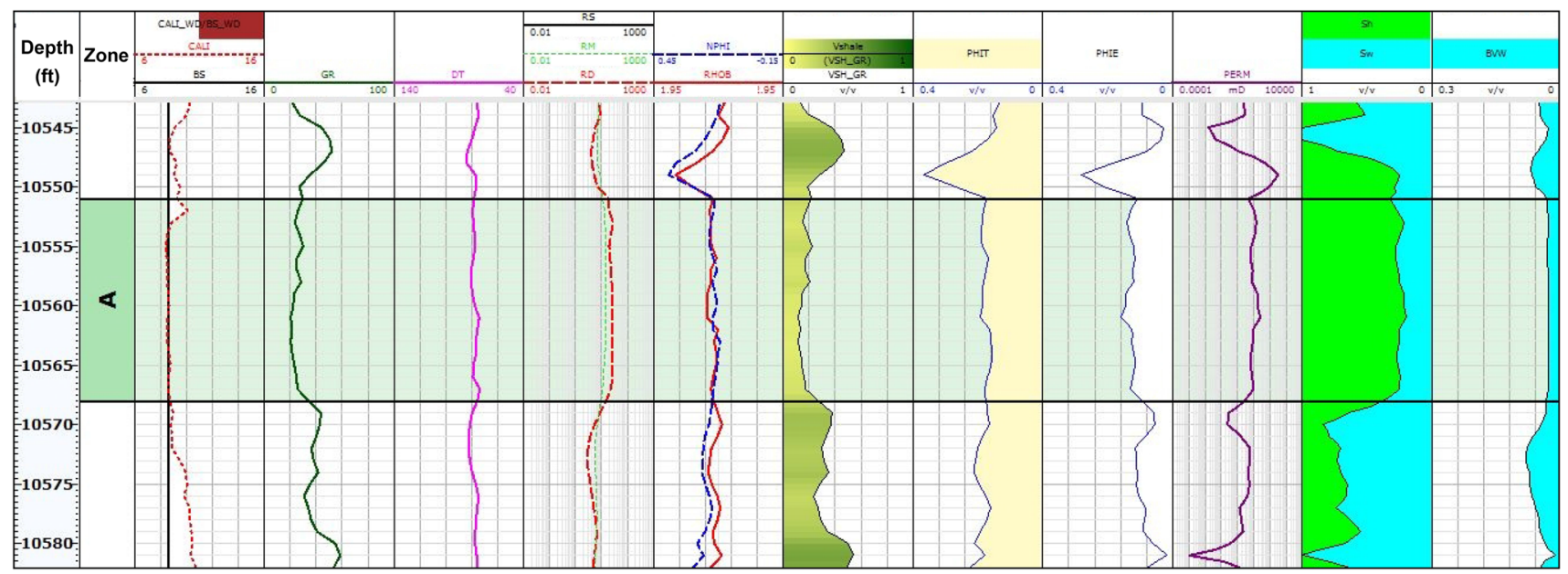

Fig. 3 Well logs with interpretation for zone A in well AG-2

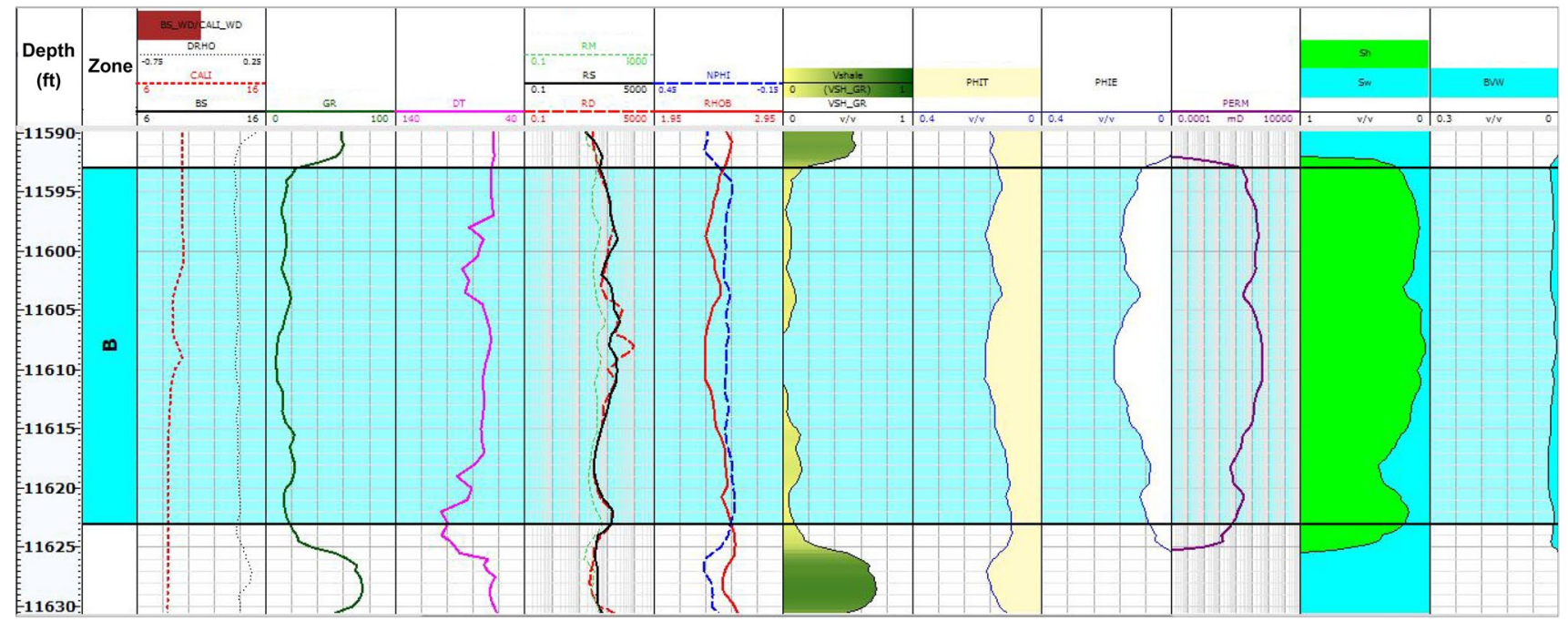

Fig. 4 Well logs with interpretation for zone B in well AG-6

\section{Results}

\section{Seismic interpretation}

The seismic horizon corresponding to the top of the Bahariya Formation exhibits a relatively strong amplitude reflector intersected by many normal faults (Figs. 8, 9, and 10). The structure maps for the inspected surface display that the ENE-WSW asymmetrical anticline is oriented toward the northeast. This anticline detached by numerous NW-SE normal faults varies in length between 8 and $15 \mathrm{~km}$ (Figs. 11 and 12).

The presence of the anticline (compressional structure) as well as normal faults (extensional structure) is evidence for the effect of the Late Cretaceous dextral wrench tectonics on the Abu Gharadig Basin. This dextral wrench was caused by the NW movement of the African Plate compared with the Laurasia Plate.

\section{Well-log evaluation}

Based on the neutron-density cross-plots of Schlumberger (1972) for the investigated zones, the plotted points cluster on and around the sandstone line, reflecting the sandy matrix of these zones, as shown in Fig. (13). Water saturation-effective porosity cross-plots (after Asqith and Gibson 1982) were created to assess the grain size in interesting zones, as displayed in Fig. (14). These plots show that the sand in these zones is coarse-grained. 


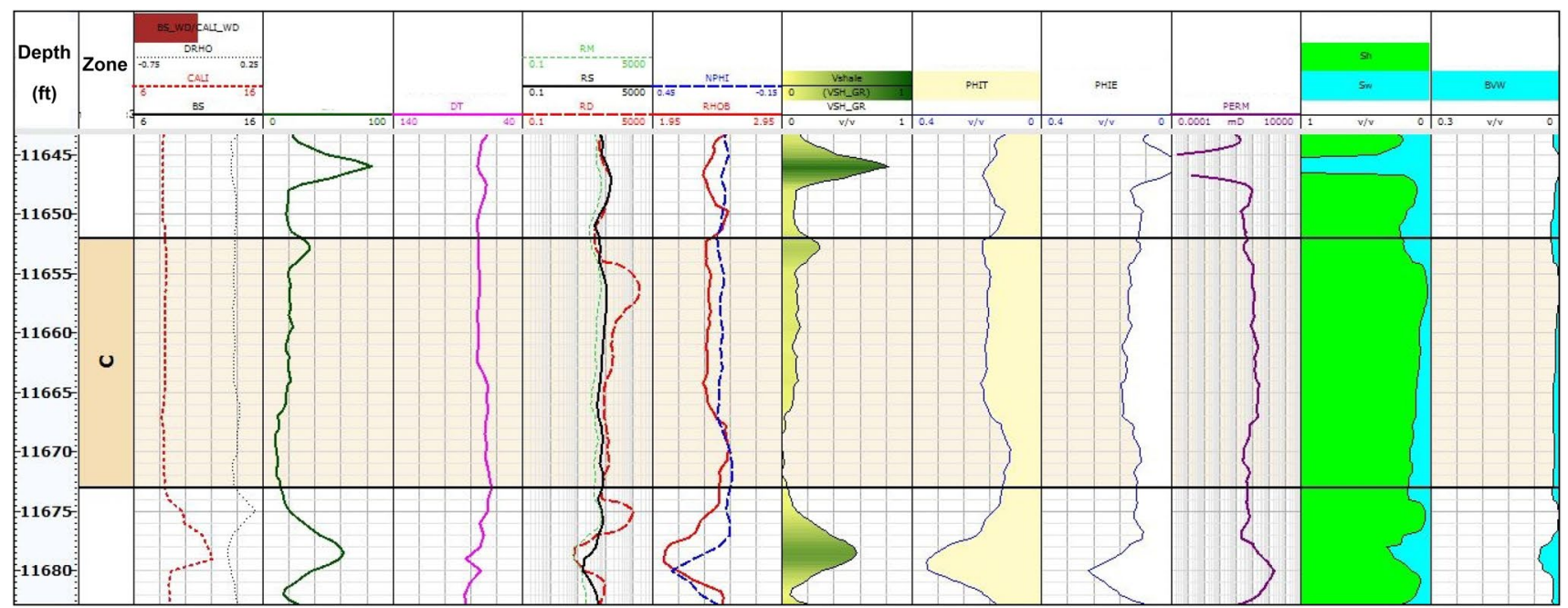

Fig. 5 Well logs with interpretation for zone C in well AG-6

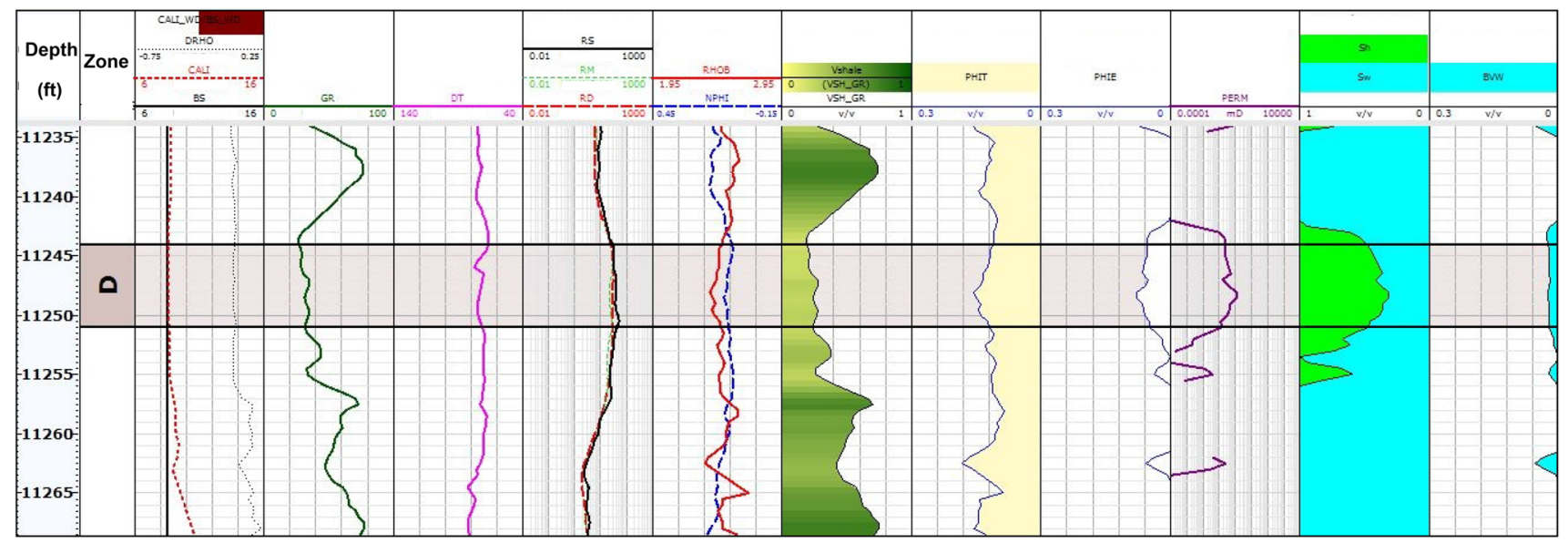

Fig. 6 Well logs with interpretation for zone D in well AG-15

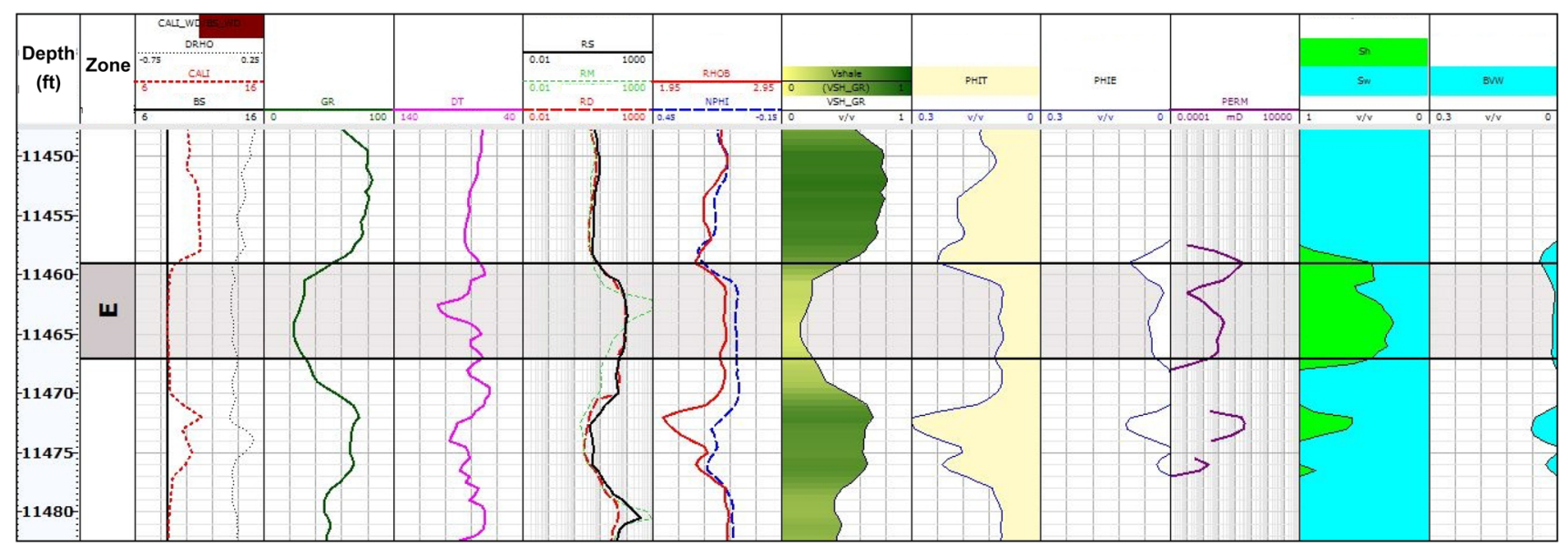

Fig. 7 Well logs with interpretation for zone E in well AG-15 


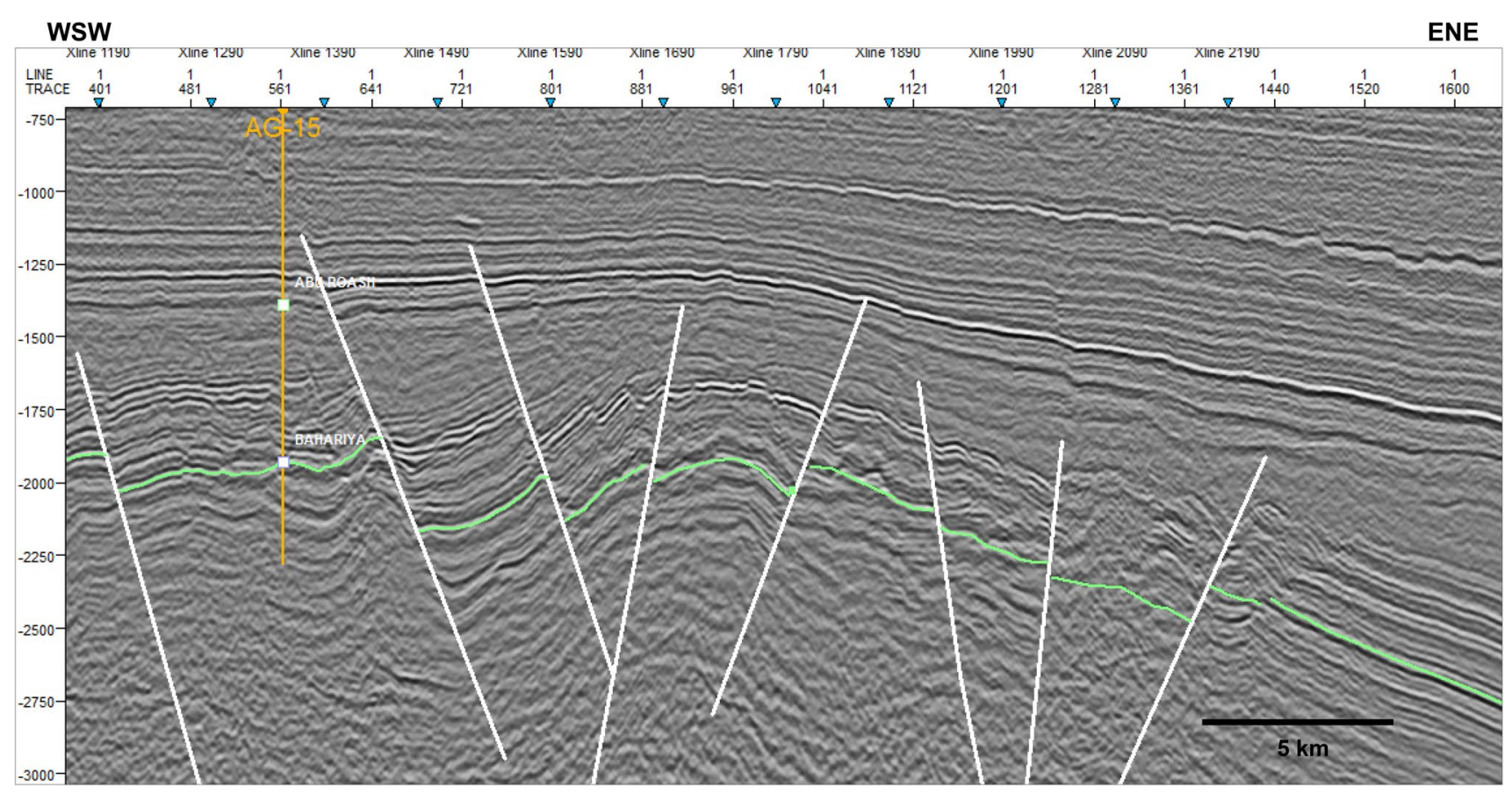

Fig. 8 Interpreted TWT seismic line No. 5240 (see Fig. 1b for line location)

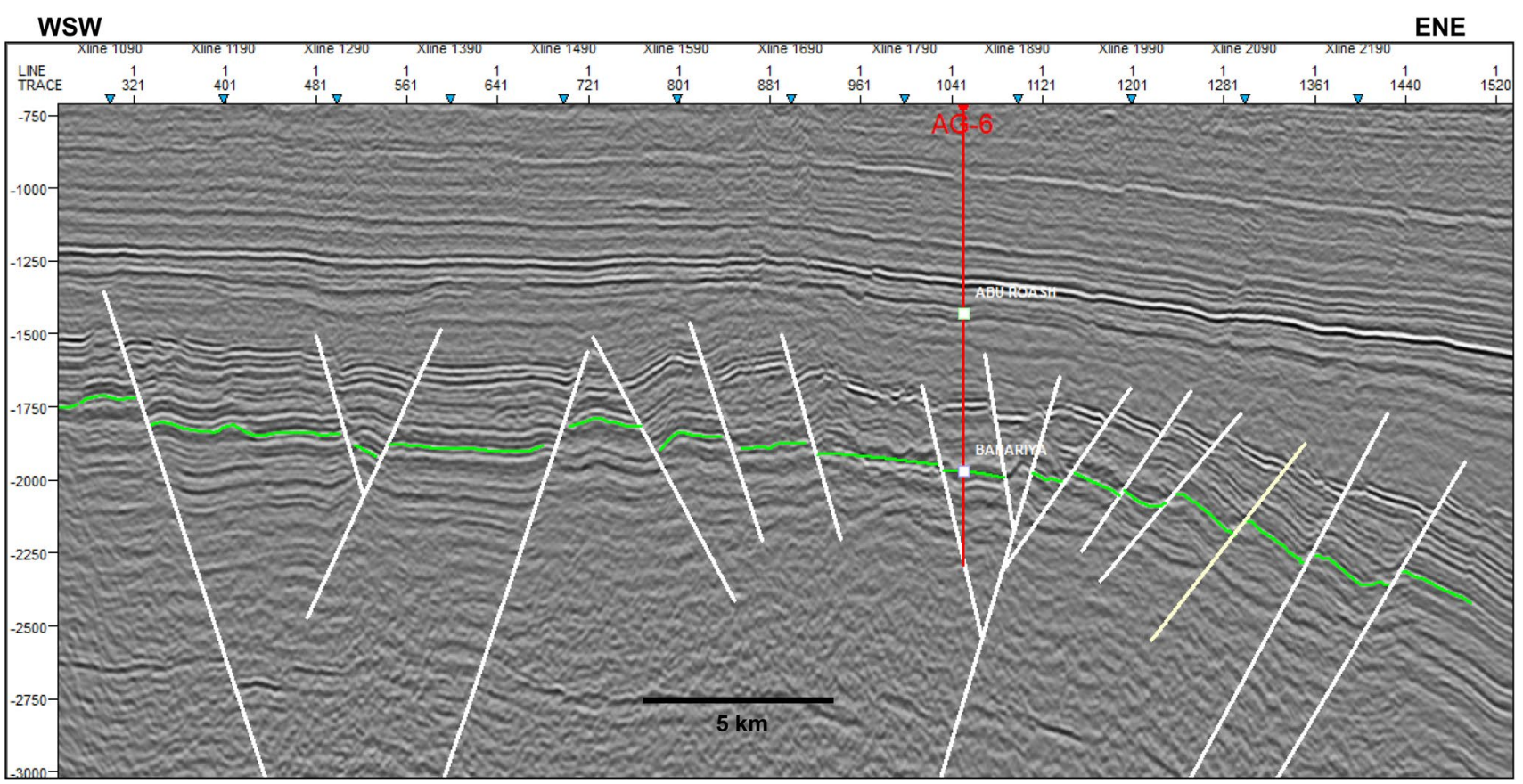

Fig. 9 Interpreted TWT seismic section No. 5340 (see Fig. 1b for line location) 


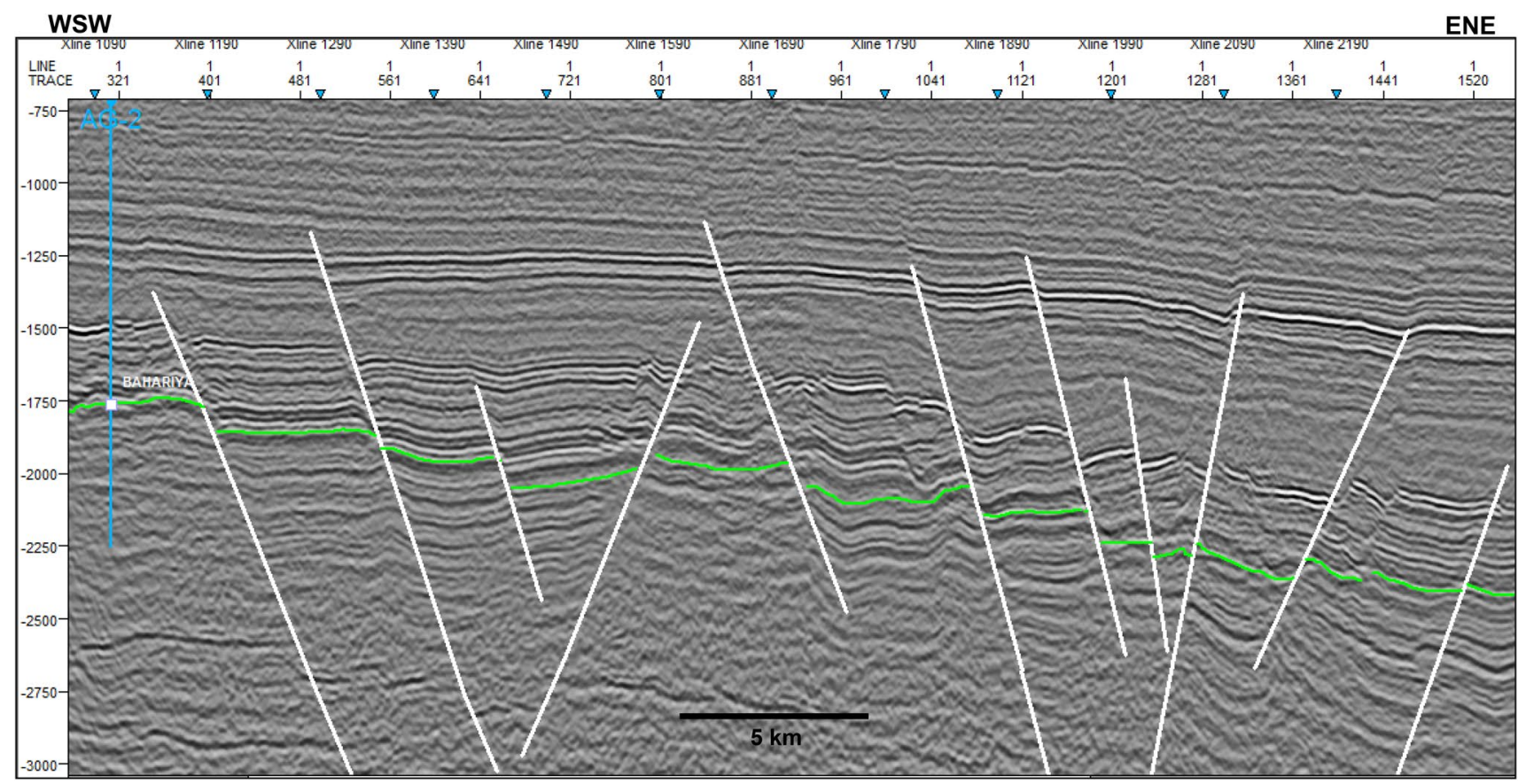

Fig. 10 TWT seismic profile No. 5440 with interpretation (see Fig. 1b for line location)

\section{Shale volume (Vsh)}

The amount of clay in the inspected zones was determined based on GR logs, that is, based on the linear equation of Asquith and Gibson (1982), as demonstrated in Figs. (3, 4, 5, 6 and 7).

The volume calculated for the shale in the study area is low. The maximum shale volume (24\%) was detected in zone $\mathrm{D}$, and the minimum value $(6.0 \%)$ was obtained in zone $\mathrm{B}$.

\section{Total porosity $\left(\phi_{T}\right)$}

The total porosity reflects the total volume of voids in a rock, which can be of primary or secondary origin. The total porosity was calculated from the neutron-density logs using the equation of Asquith and Gibson (1982) as shown in Figs. $(3,4,5,6$ and 7$)$.

The highest average total porosity (18\%) was recorded in zone $\mathrm{A}$, and the lowest value (11\%) was obtained in zone $\mathrm{E}$.

\section{Effective porosity $\left(\phi_{\mathrm{e}}\right)$}

The effective porosity measures only the interconnected voids based on which fluids can be transmitted (Asquith and
Gibson 1982). It can be determined by using the equation of Asquith and Gibson (1982) as presented in Figs. (3, 4, 5, 6 and 7).

The highest average effective porosity (13\%) was recorded in zones $\mathrm{A}, \mathrm{B}$, and $\mathrm{C}$, whereas the lowest value $(5 \%)$ was obtained in zone $\mathrm{E}$.

\section{Absolute permeability}

The absolute permeability of the examined zones was determined using the equation of Wyllie and Rose (1950) as displayed in Figs. (3, 4, 5, 6 and 7).

The average values of the absolute permeability are high in zones $\mathrm{A}(10.26 \mathrm{mD}), \mathrm{B}(13.93 \mathrm{mD})$, and $\mathrm{C}(10.29 \mathrm{mD})$, whereas they are low in zones $\mathrm{D}(0.43 \mathrm{mD})$ and $\mathrm{E}(0.35$ $\mathrm{mD})$.

\section{Water saturation $\left(\mathrm{S}_{\mathrm{w}}\right)$}

The water saturation of the zones was computed using the Indonesia model (Poupon and Leveaux 1971).

The calculated water saturation is displayed in blue in Figs. 3, 4, 5, 6, and 7; the green color marks the hydrocarbon saturation. 


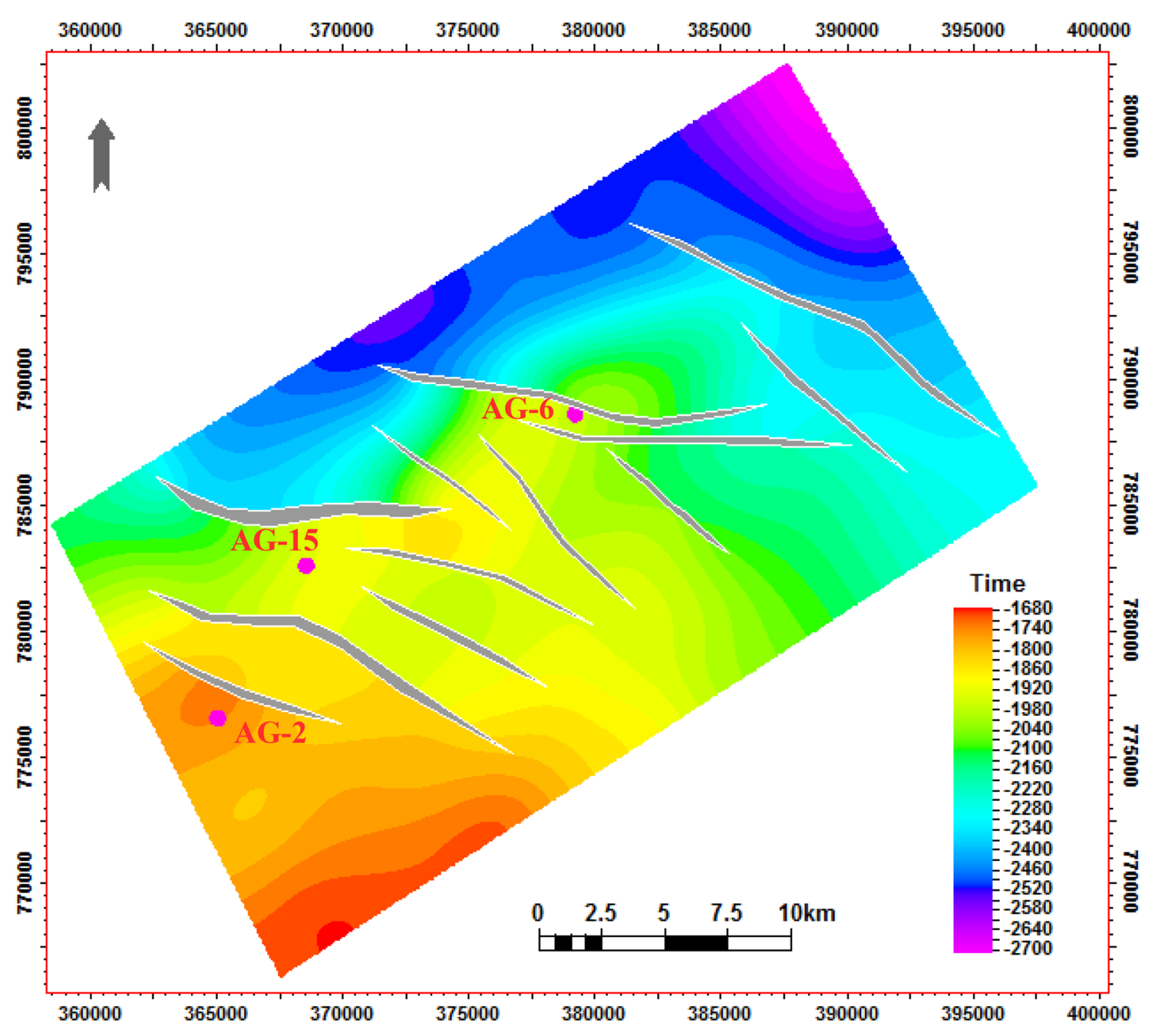

Fig. 11 Time-structure map for the topmost horizon of the Bahariya Formation in the study area

The highest average water saturation of $40 \%$ (i.e., the hydrocarbon saturation equals $60 \%$ ) was recorded in zones $\mathrm{D}$ and $\mathrm{E}$, whereas a low water saturation was detected in zones A (26\%), B (16\%), and C (11\%).

Figure (15) presents the water saturation-effective porosity plots for the studied zones. These plots clearly display that zones $\mathrm{A}, \mathrm{B}$, and $\mathrm{C}$ are the most promising zones with respect to the hydrocarbon reservoir potential because they have the highest $\phi_{e}$ and lowest $S_{w}$.

\section{BVW}

The BVW was determined by multiplying the water saturation with the porosity. If the calculated BVW values are low and constant in a specific zone, water-free hydrocarbon production can be predicted for this zone. The BVW can be determined with the equation of Buckles (1965).
The calculated BVW values are presented in blue in Figs. (3, 4, 5, 6 and 7). The maximum BVW (0.03) was detected in zone $\mathrm{A}$, and the minimum value $(0.01 \%)$ was obtained in zone C. However, zones B, D, and E have a BVW of 0.02 .

\section{Relative permeability and water cut}

The fluid through production process of a hydrocarbon reservoir can be determined based on the measurement of different parameters including $K_{\text {ro }}$ (relative permeability to oil), $K_{\mathrm{rw}}$ (relative permeability to water), and $W c$ (water cut), which refers to the amount of water associated with the produced oil. All parameters are controlled by the $S_{\text {wirr }}$ value (irreducible water saturation). The $S_{\text {wirr }}$ of an individual zone primarily depends on the formation factor (Tables 1, 2, 3, 4, and 5). 


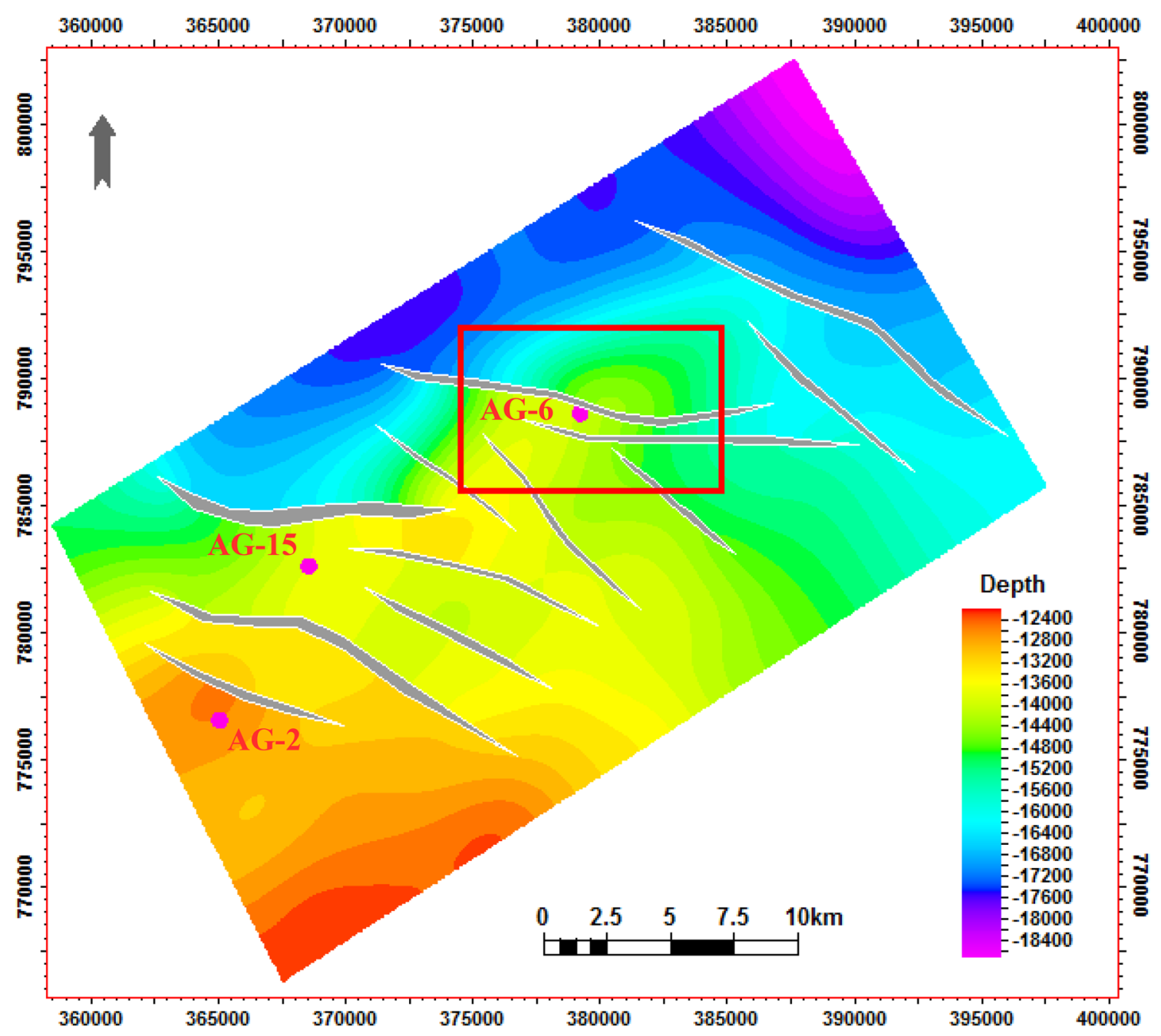

Fig. 12 Depth-structure map for the topmost horizon of the Bahariya Formation in the study area. Note that the area outlined by the red polygon represents the crest of the mapped anticline for which the drilling of more wells close to well AG-6 is highly recommended

Several cross-plots display the correlation between water saturation $\left(S_{w}\right)$ and irreducible water saturation $\left(S_{\text {wirr }}\right)$ in the examined zones (after Asquith and Gibson 1982), which have been constructed to represent the quality of the Bahariya reservoir in the investigated wells. These plots reveal that zones $\mathrm{B}$ and $\mathrm{C}$ have the highest oil potential because they contain the most points (above $k_{\mathrm{ro}}=1$, Fig. 16; below $k_{\mathrm{rw}}=0$, Fig. 17; and close to $W_{c}=0$, Fig. 18).
Zones B and C display similar hydraulic characteristics because they represent the same flow units (FZI; Amaefule et al. 1993; Fig. 19). Both zones have the same rock quality and a similar r35 value (Winland 1972 and 1976), which exceeds $2 \mu$, reflecting a better flow quality compared with zones D and E (Fig. 20).

The results of this study were verified with the results of drill stem tests (DST) for wells AG-2 and AG-15. The DST 


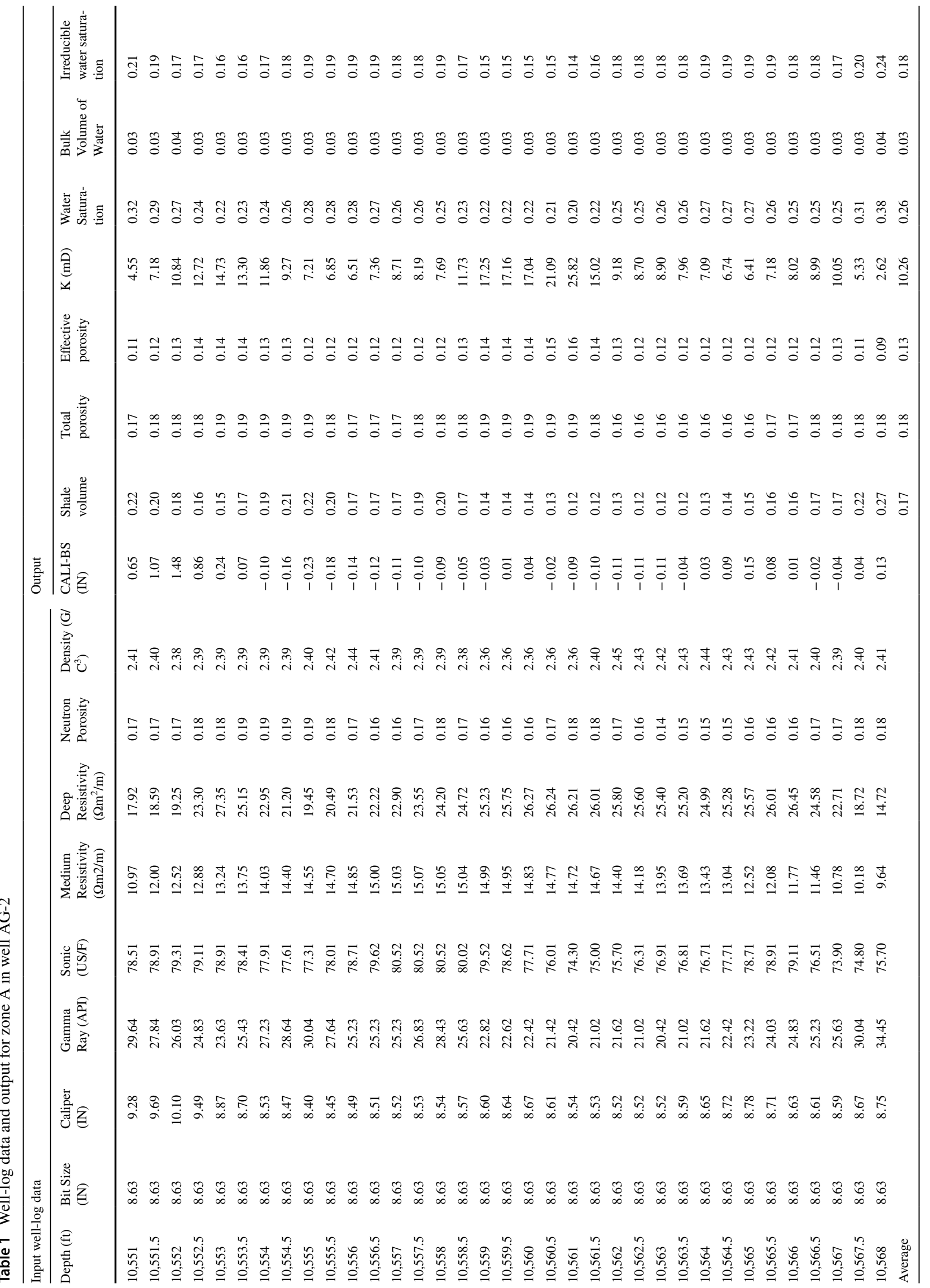




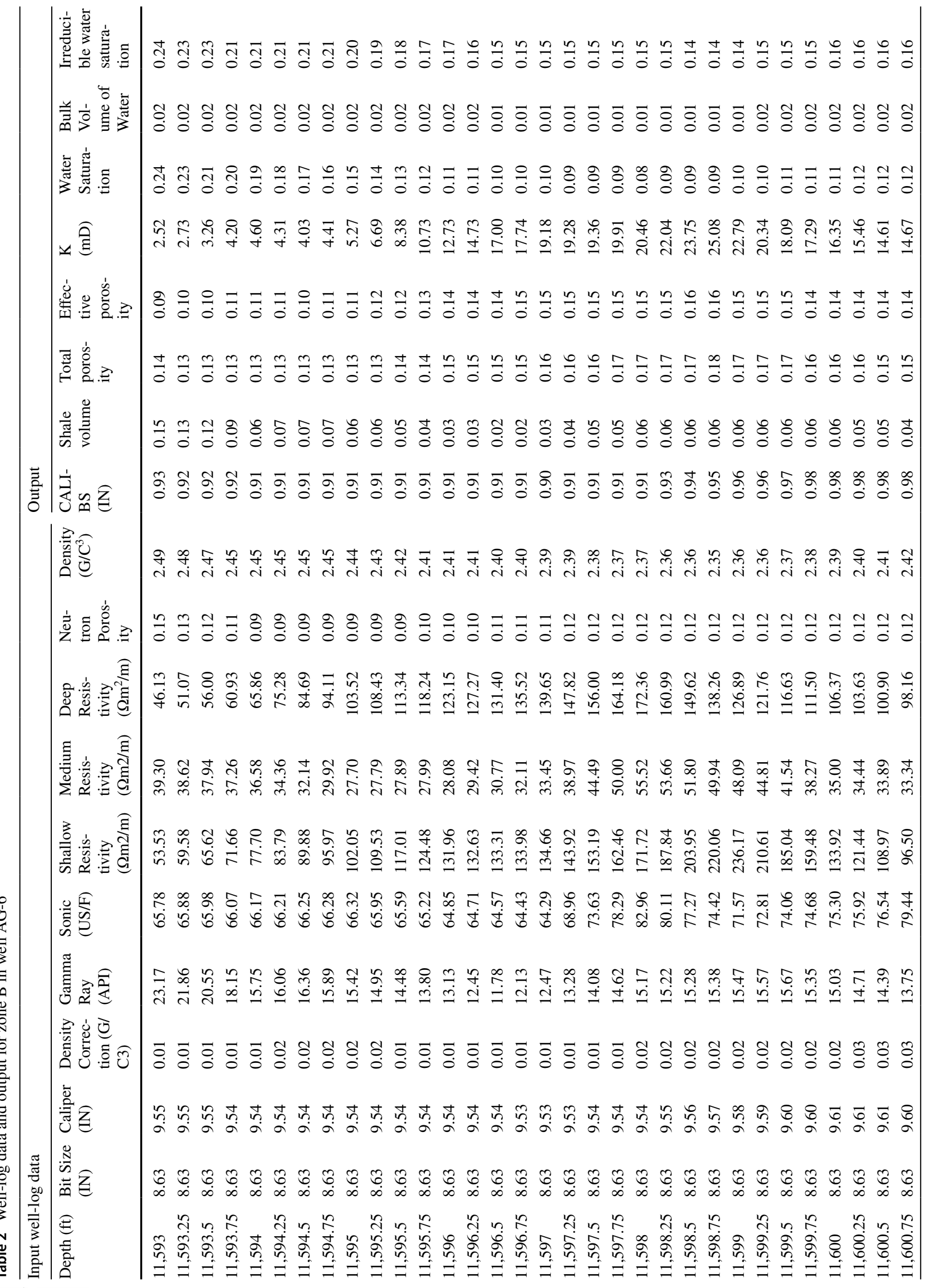




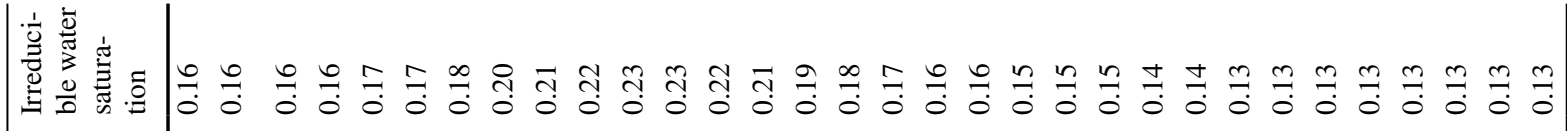

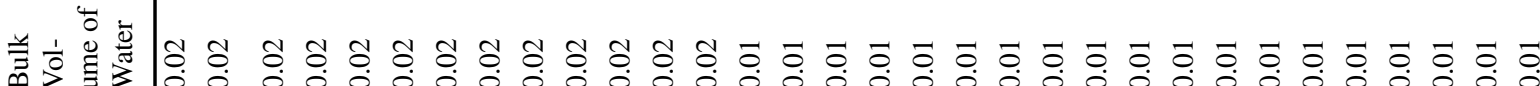

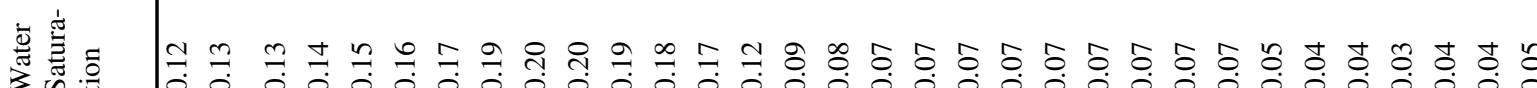

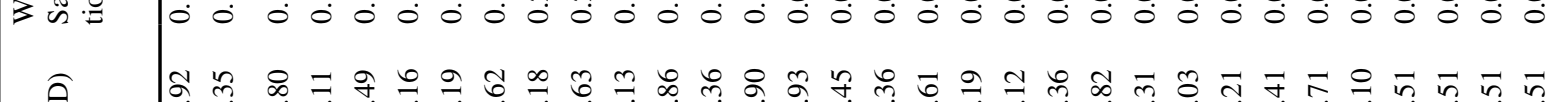

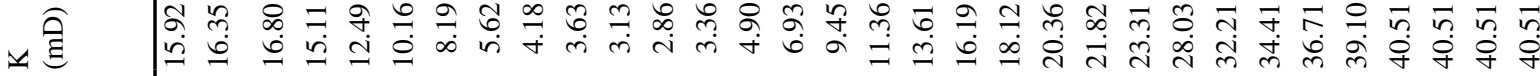

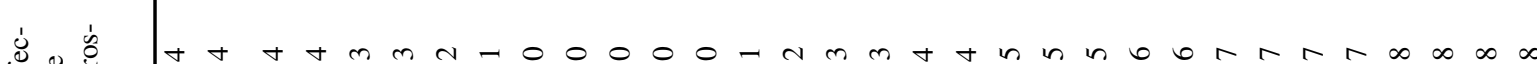

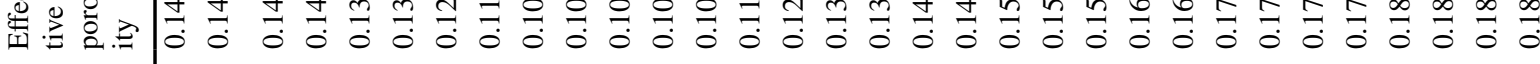

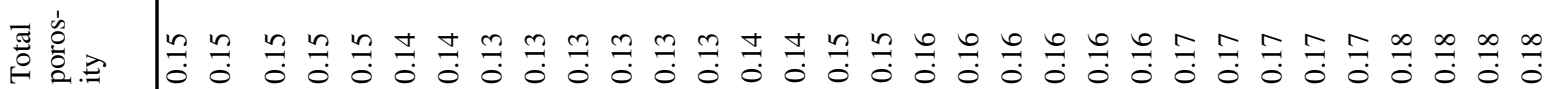
步率 言|

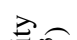

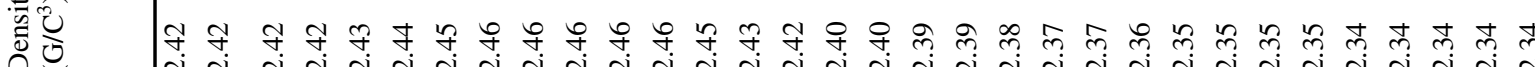

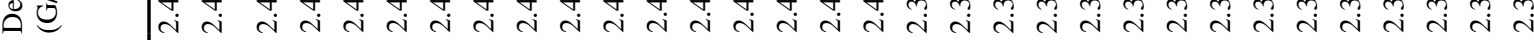

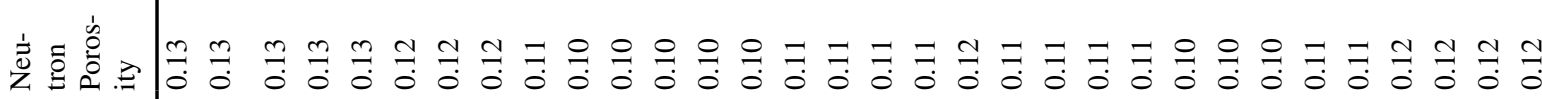

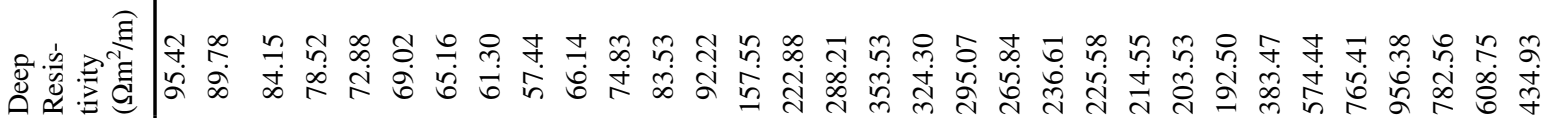
छ

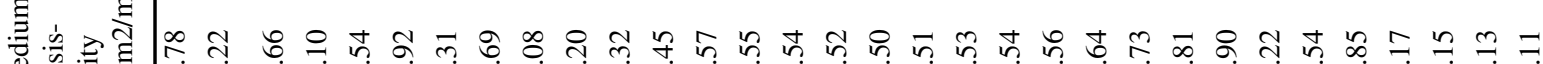

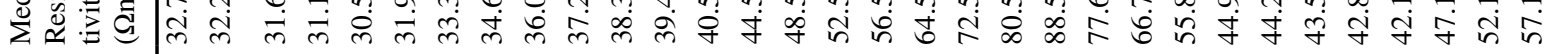

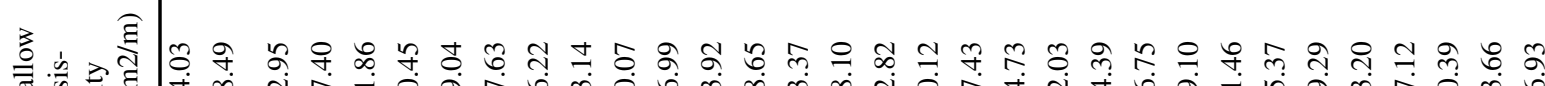

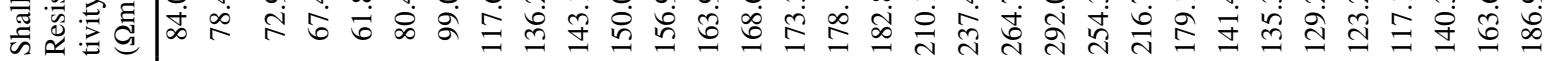

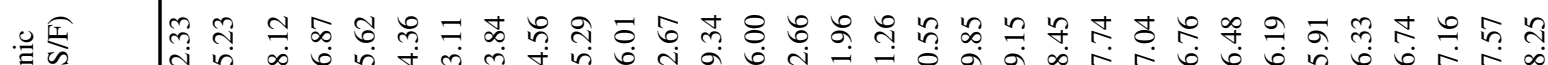

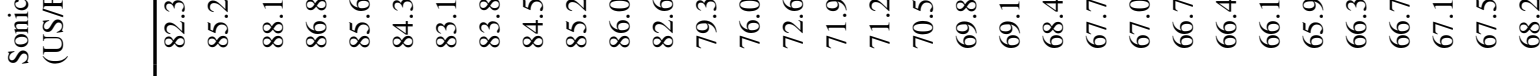

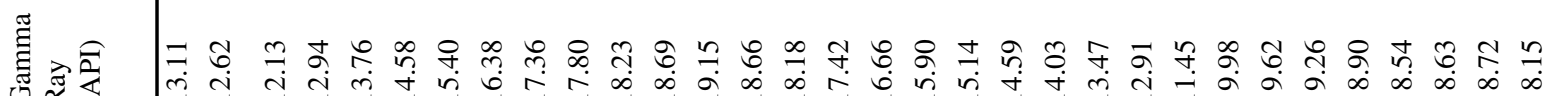

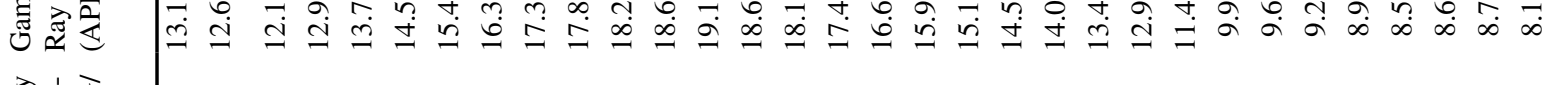

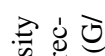
节 Uై $\stackrel{8}{8}$ in

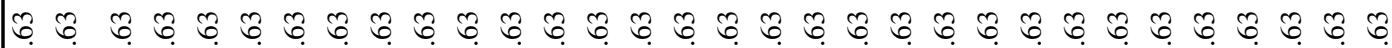

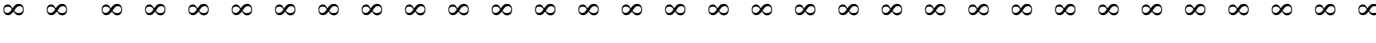

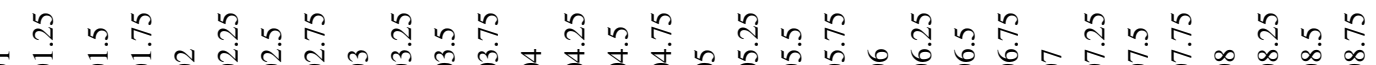
ठ

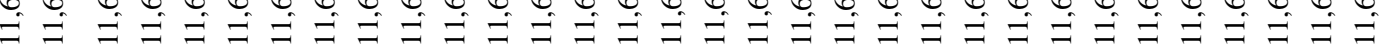




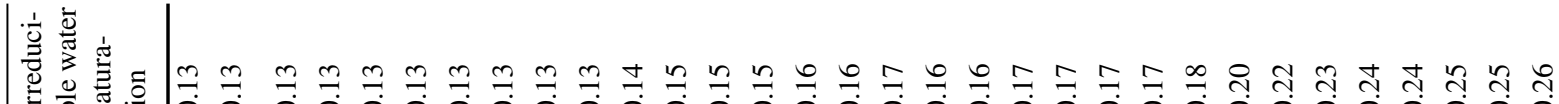

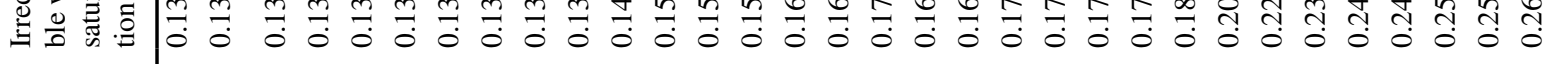

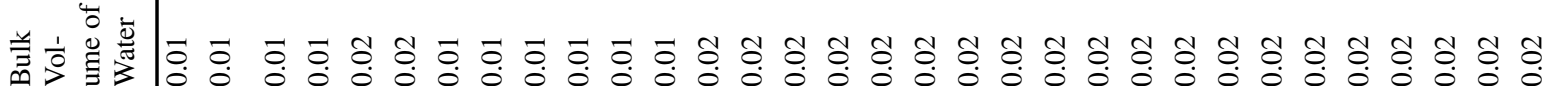
预

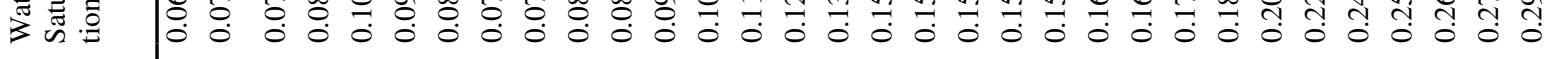

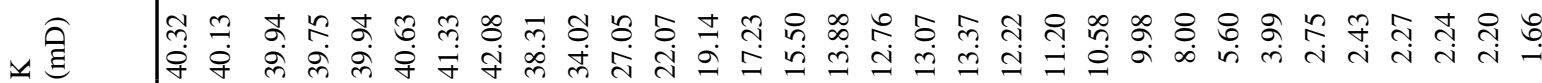
ن.

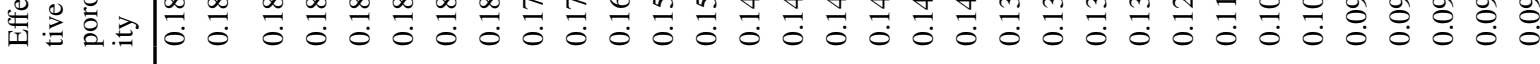
퓸

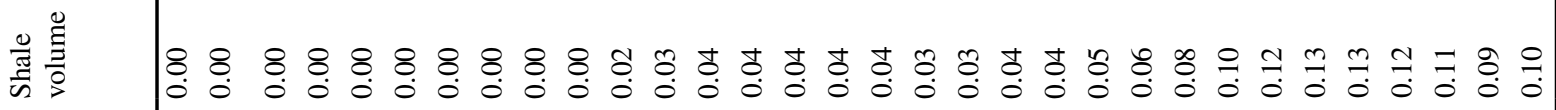

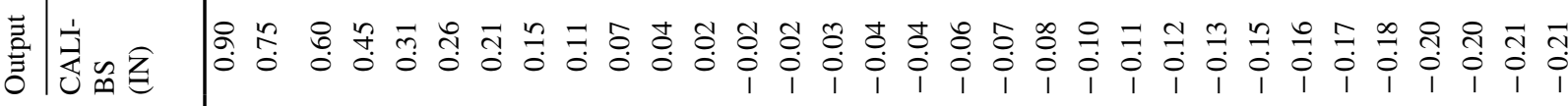
3

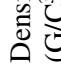

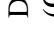

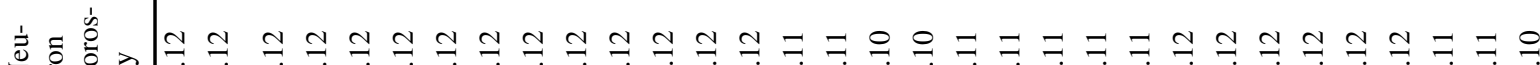

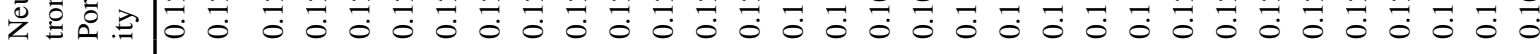

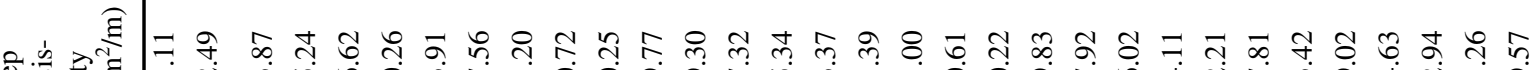

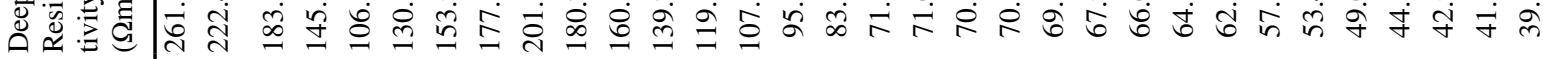
छิ

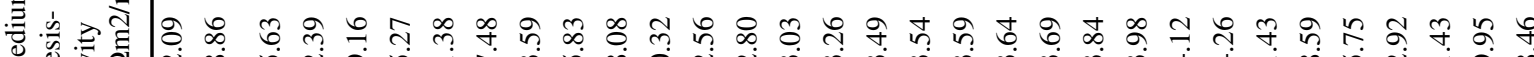

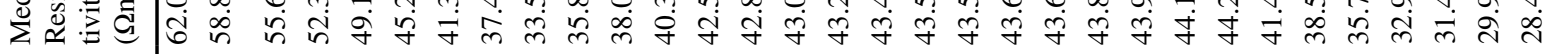
z)

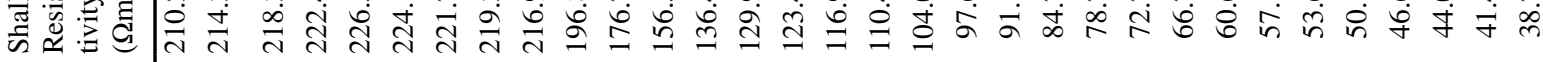

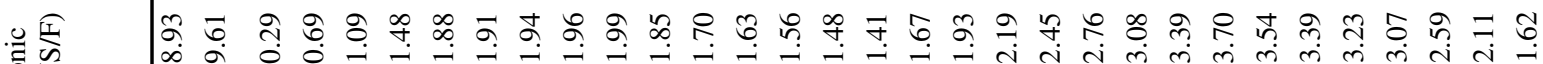

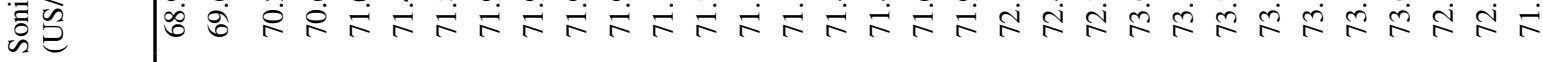
节

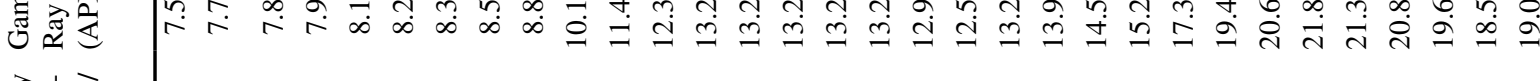
त्ञ

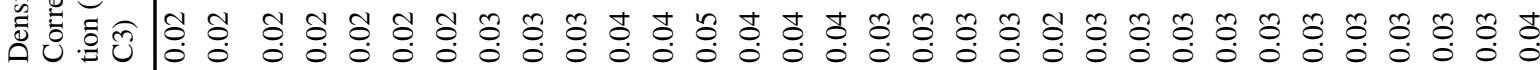
$\dot{\partial}$

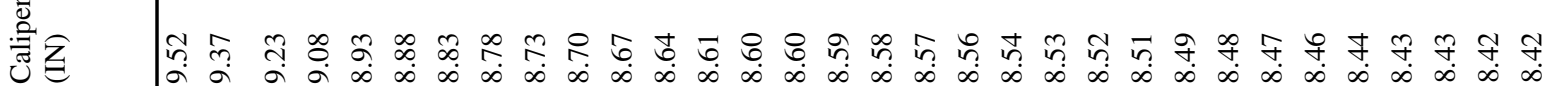

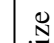
in $\widehat{Z}$

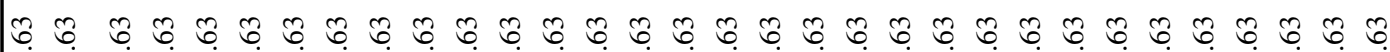

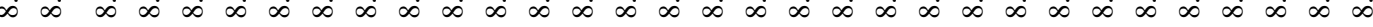

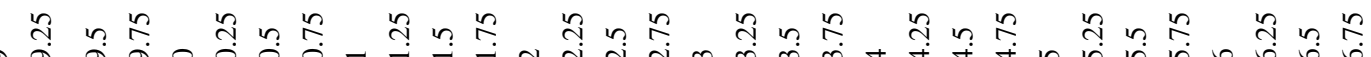
ठิ 


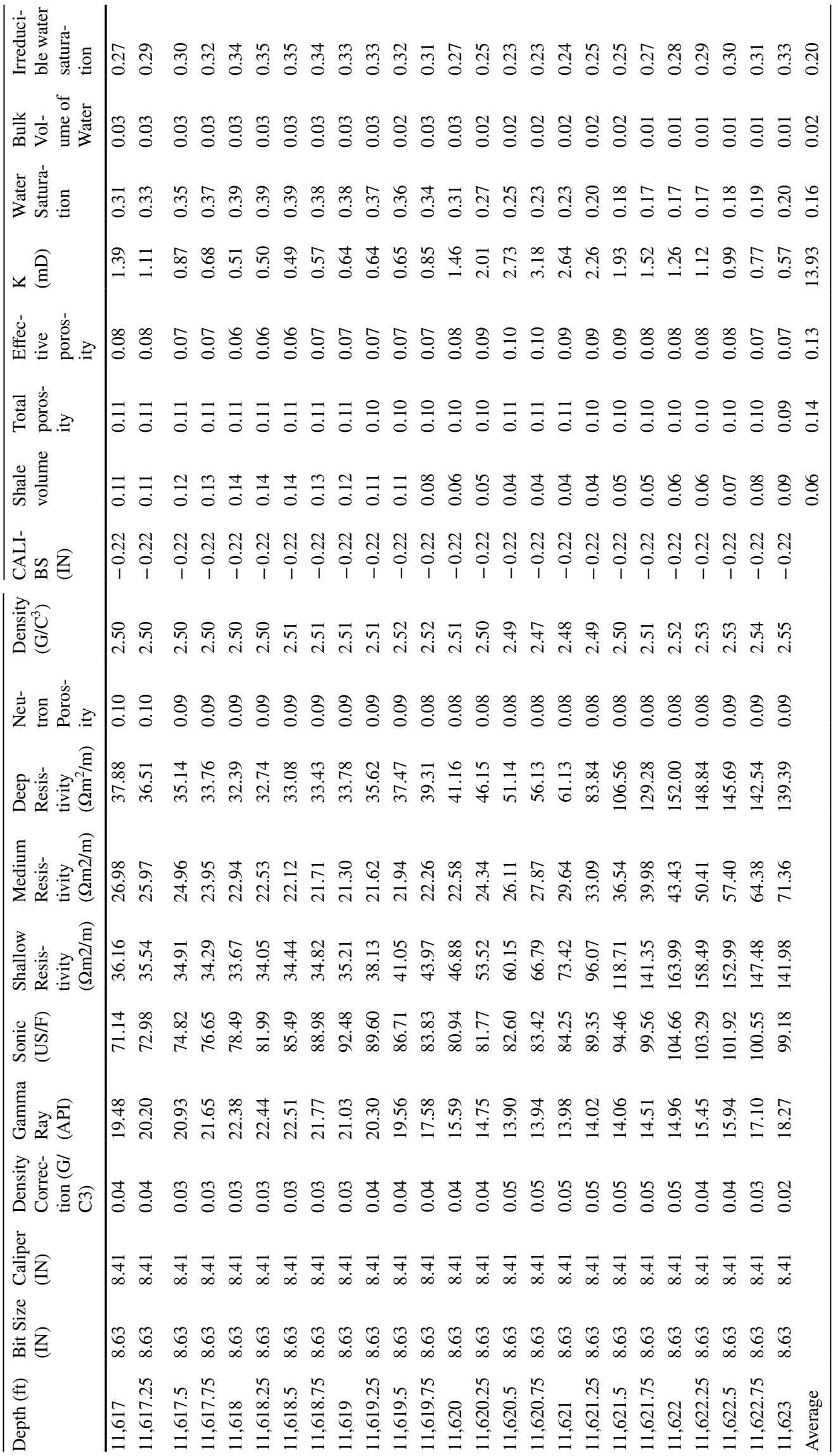




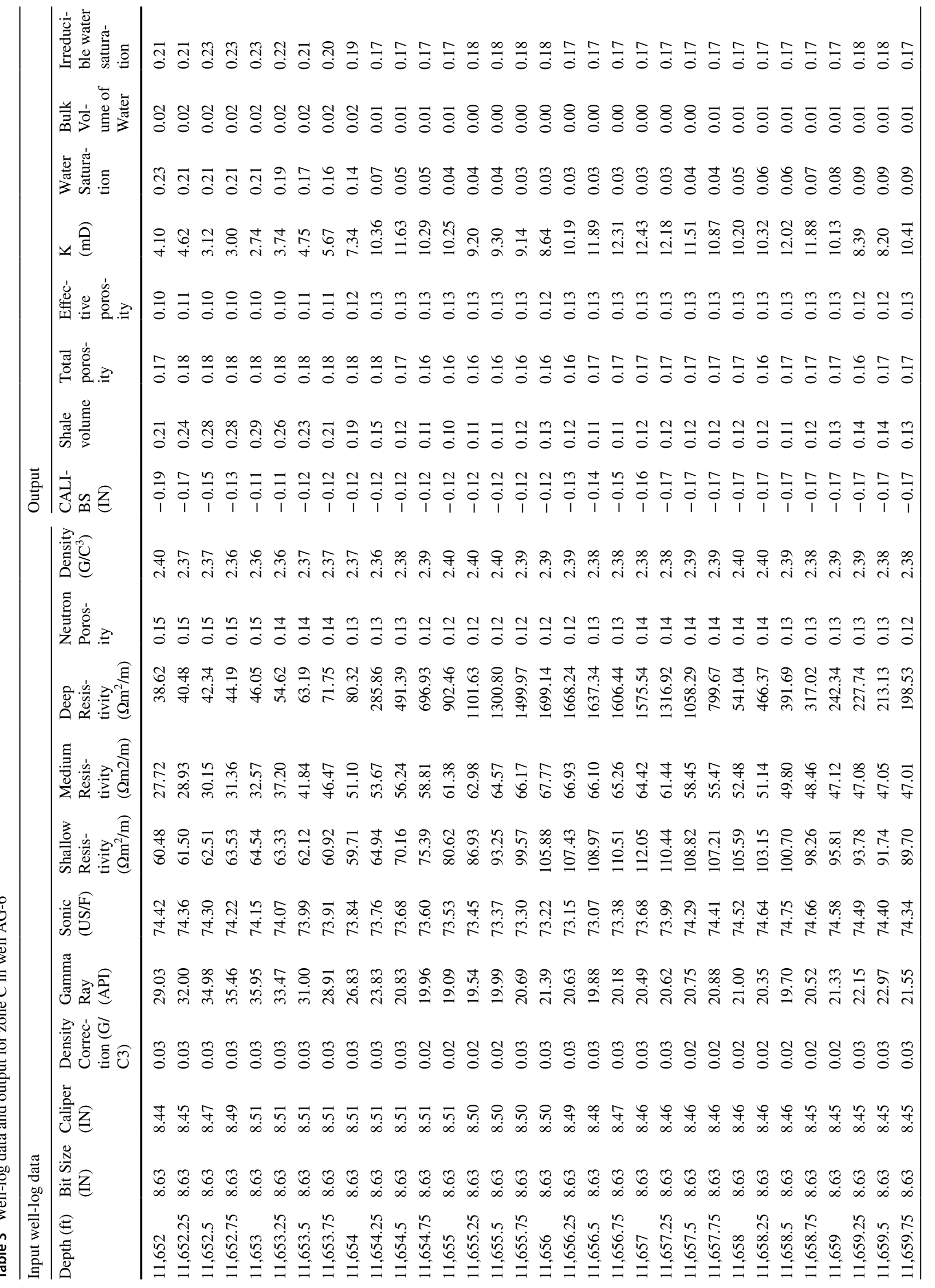




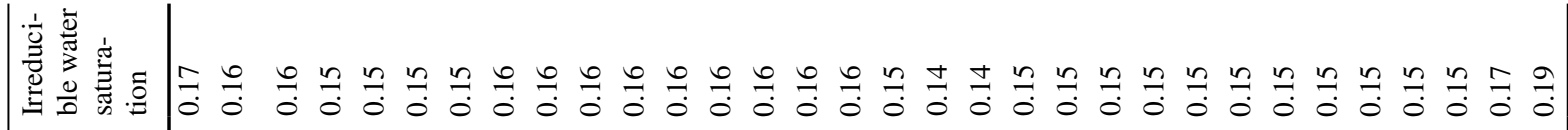

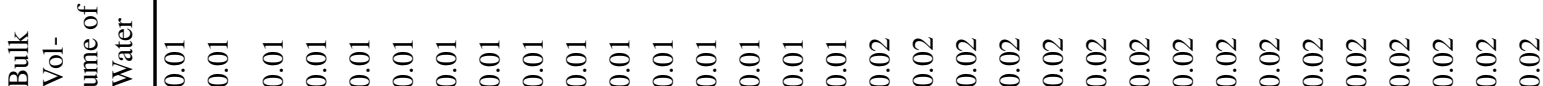
矛蒫 出 दิ

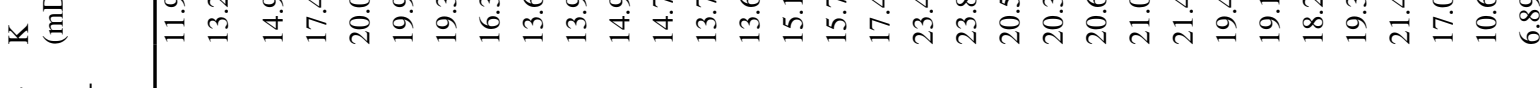

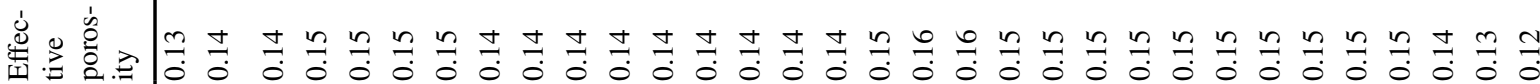
สํํㅇ

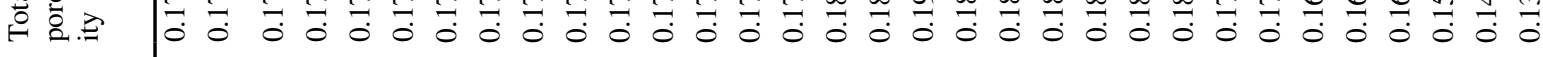
学

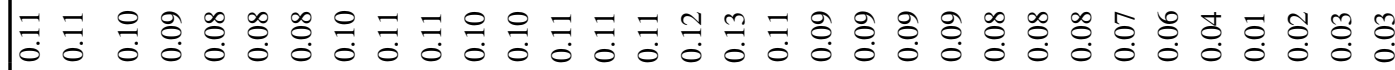

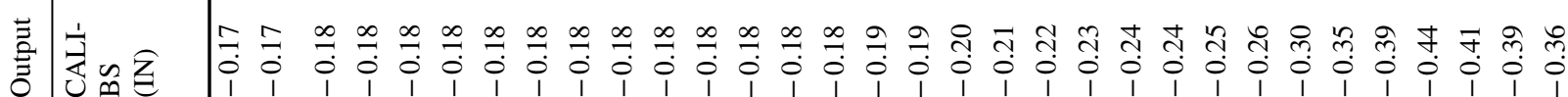

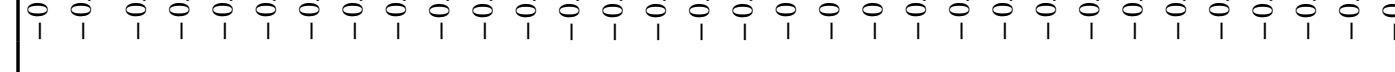

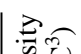

这

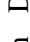

茟

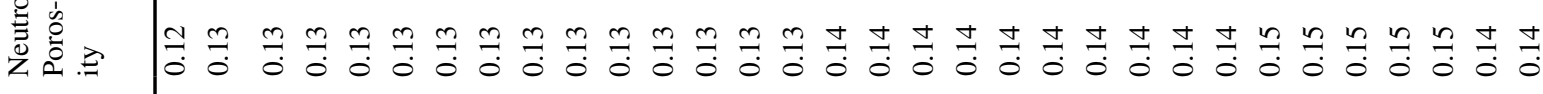

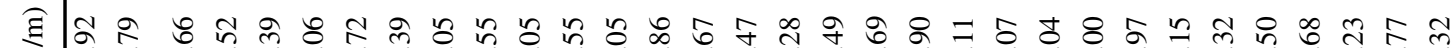

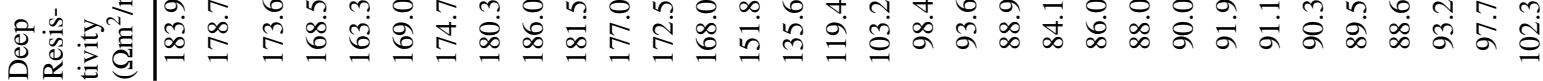
है

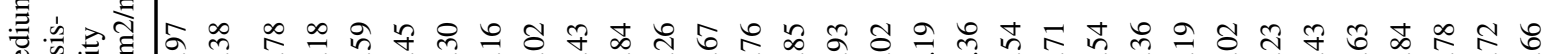

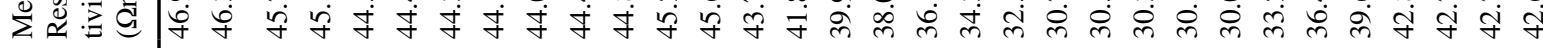

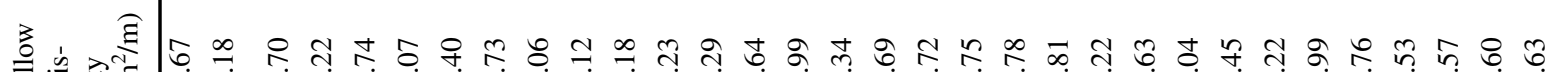

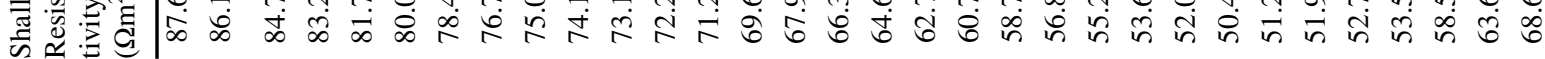

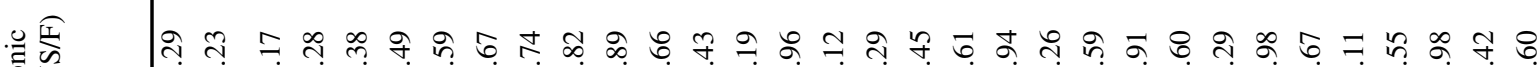

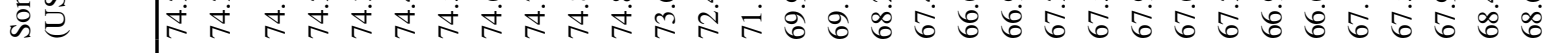

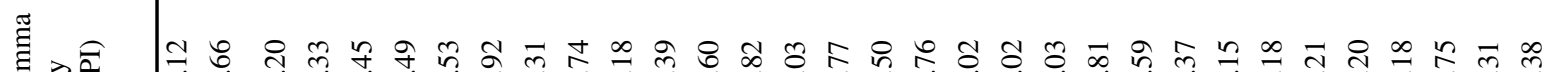

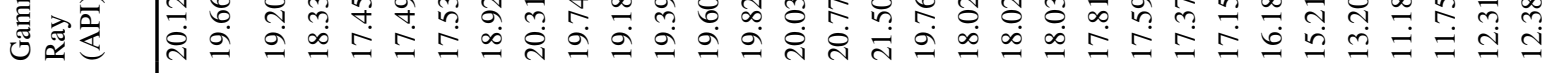

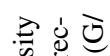
ค̆

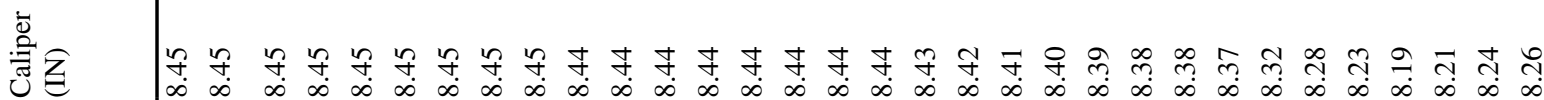

ชิ

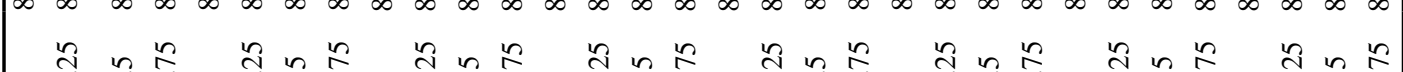

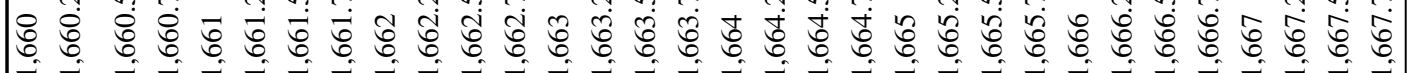

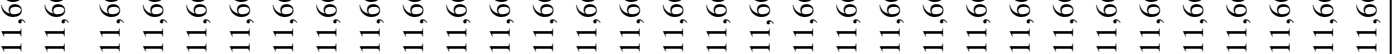




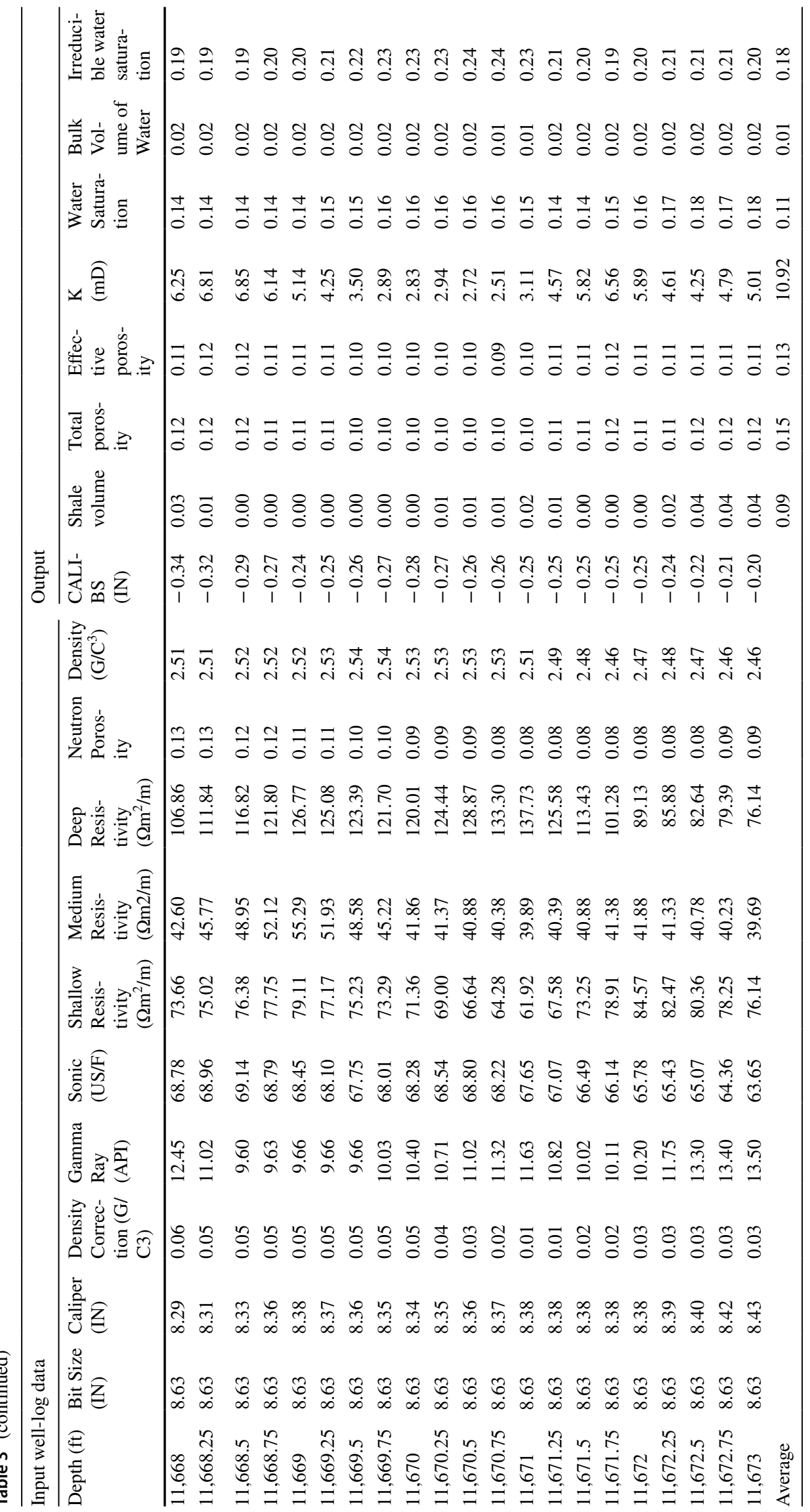




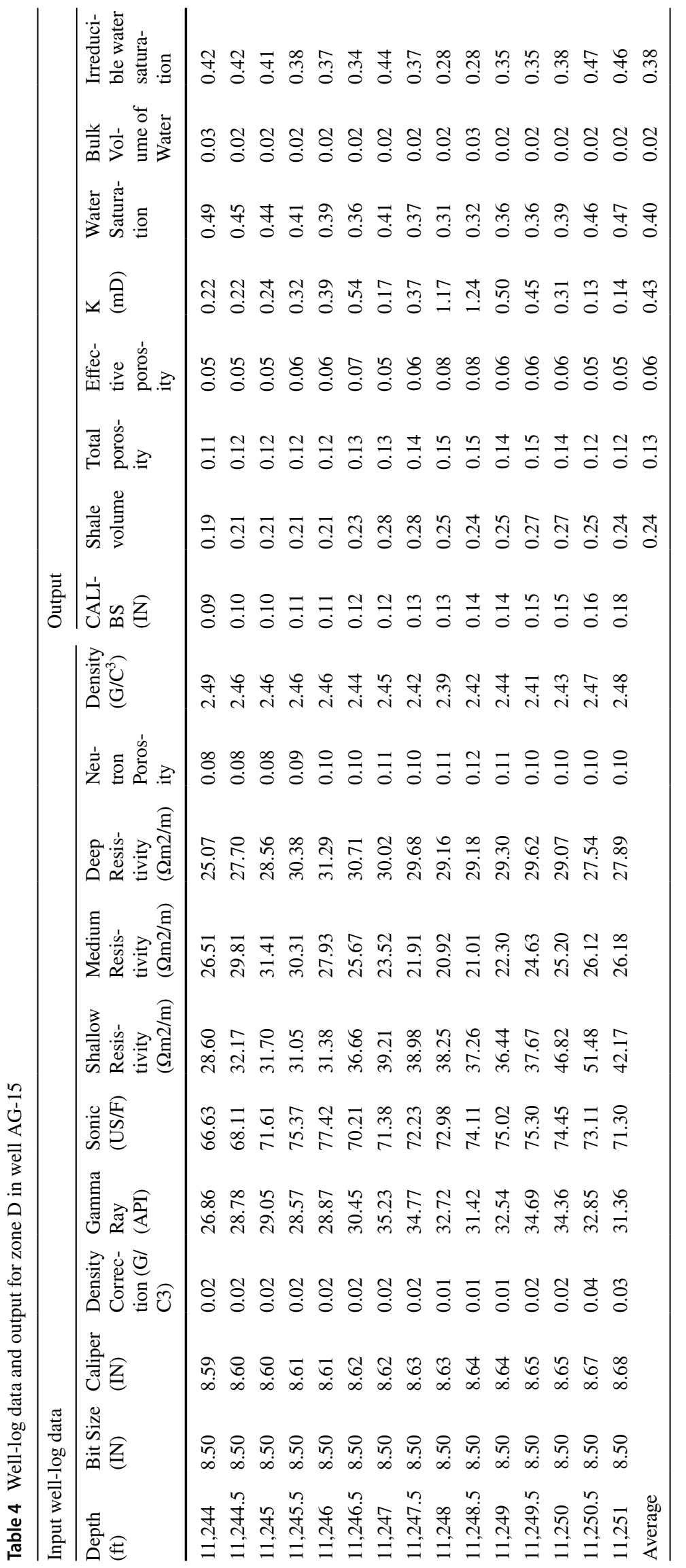




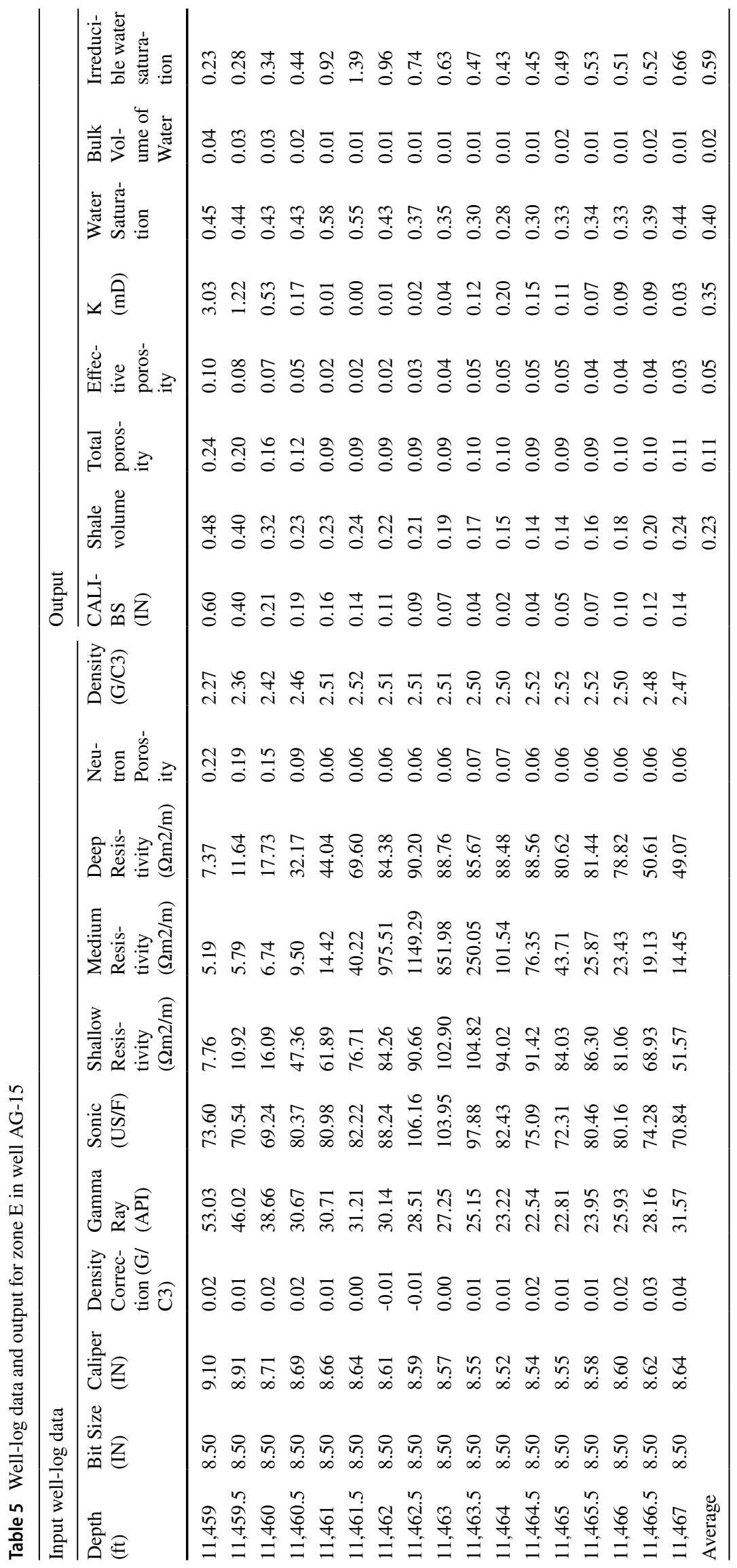



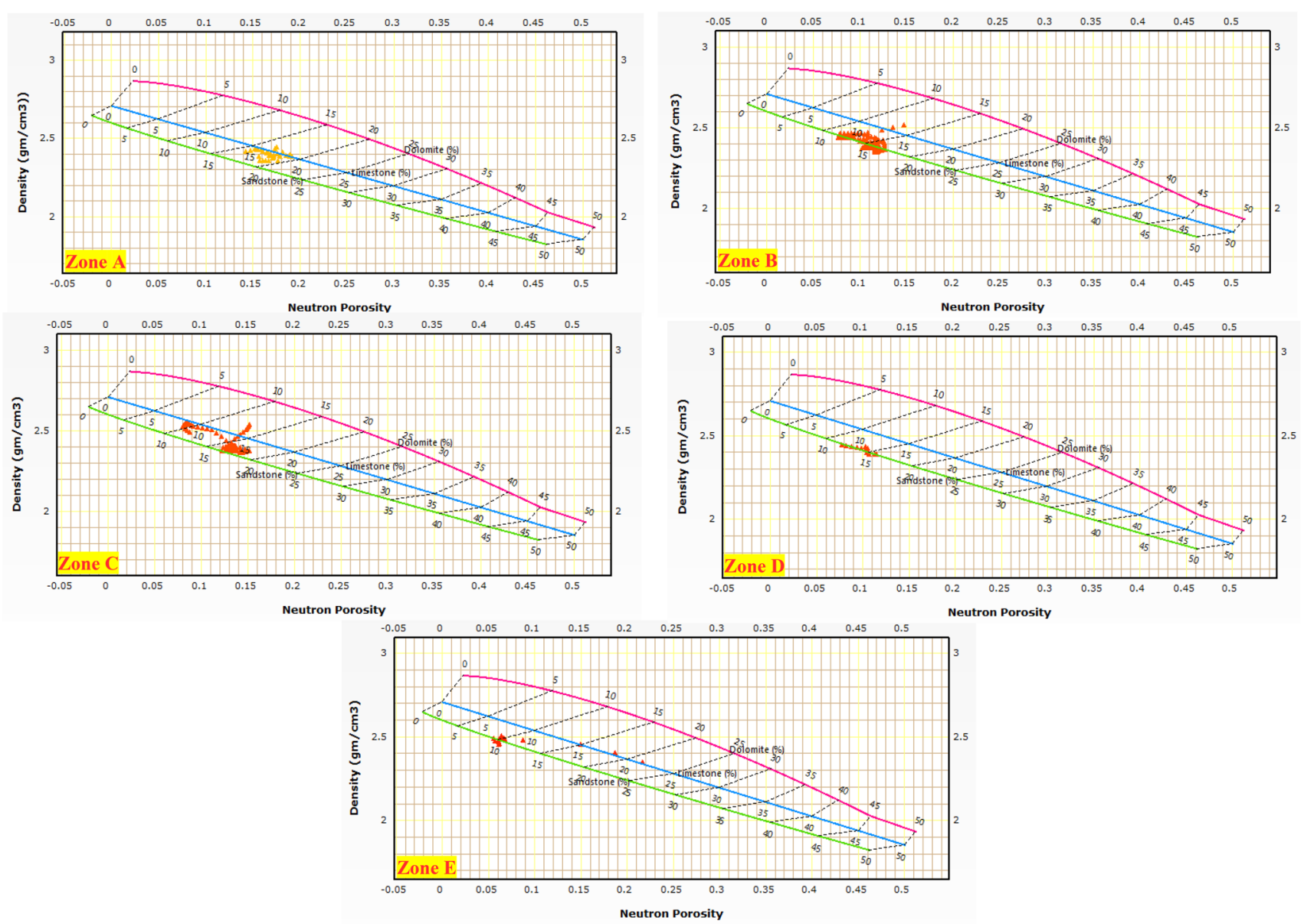

Fig. 13 Density-neutron cross-plot (after Schlumberger 1972) for the examined zones within the Bahariya Formation in the Abu Gharadig Field 

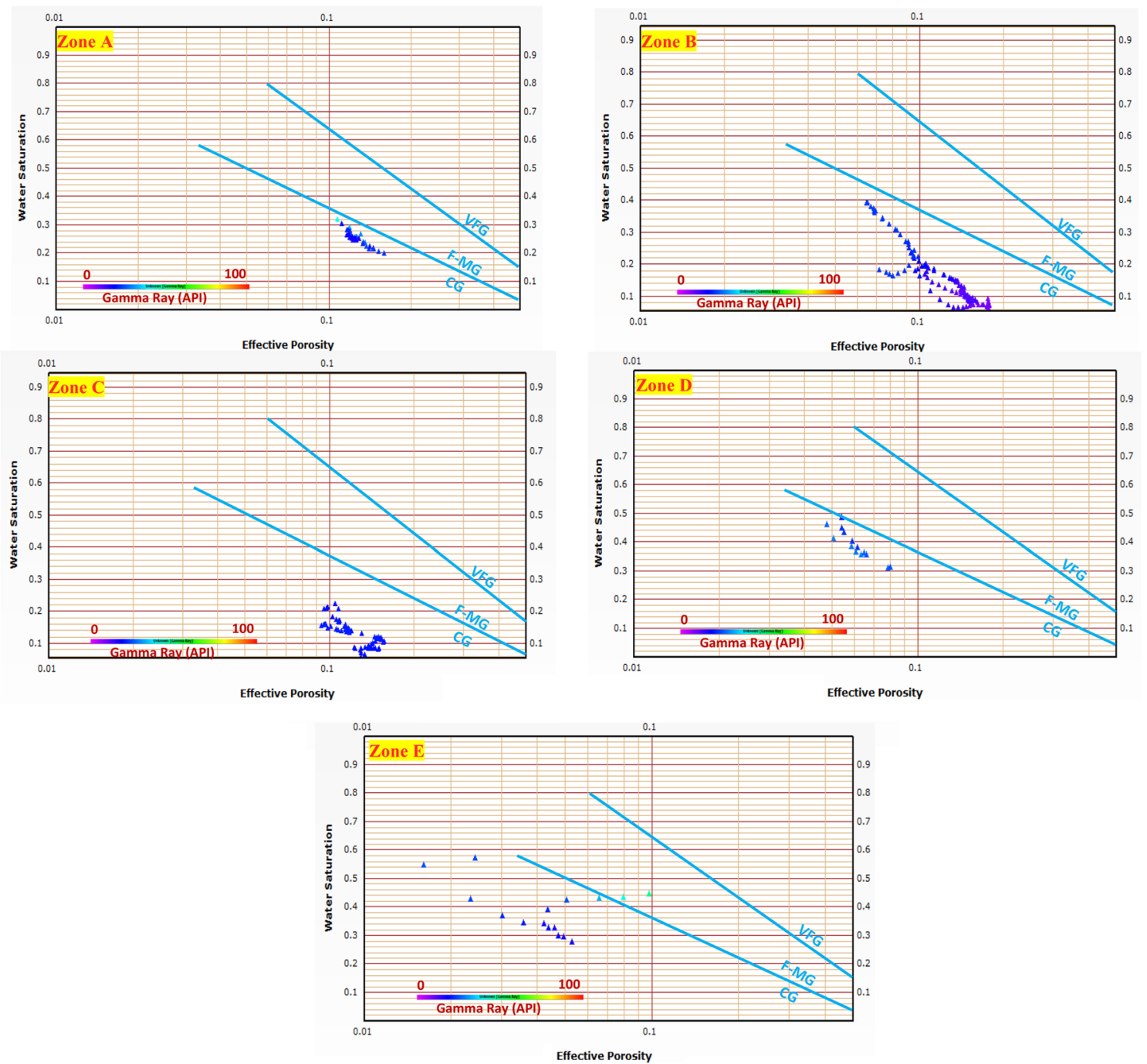

Fig. 14 Water saturation-effective porosity cross-plot (after Asquith and Gibson 1982) showing the grain size distribution in the investigated zones within the Bahariya Formation in the Abu Gharadig Field 

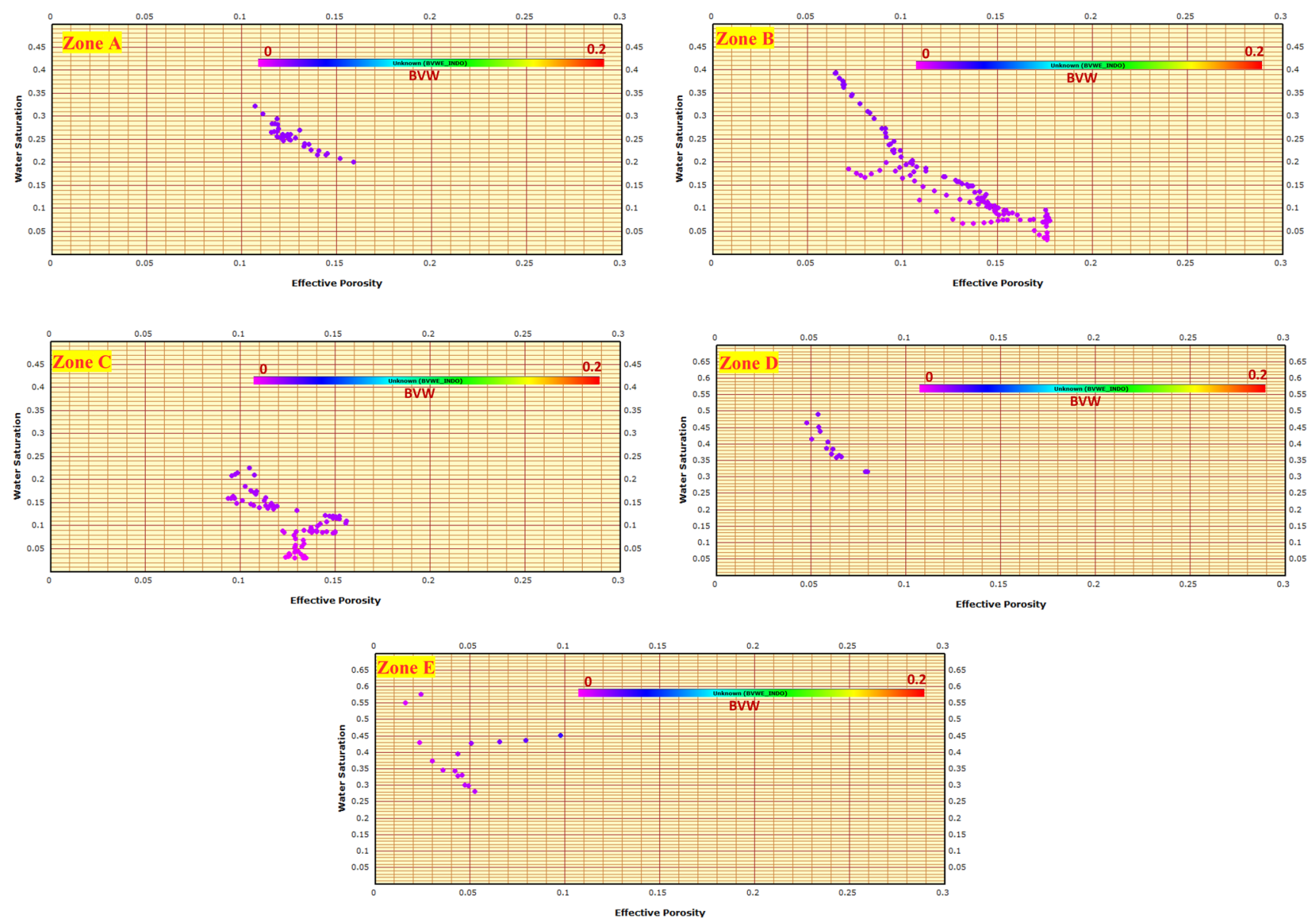

Fig. 15 Water saturation-effective porosity plot showing the investigated zones within the Bahariya Formation in the Abu Gharadig Field 

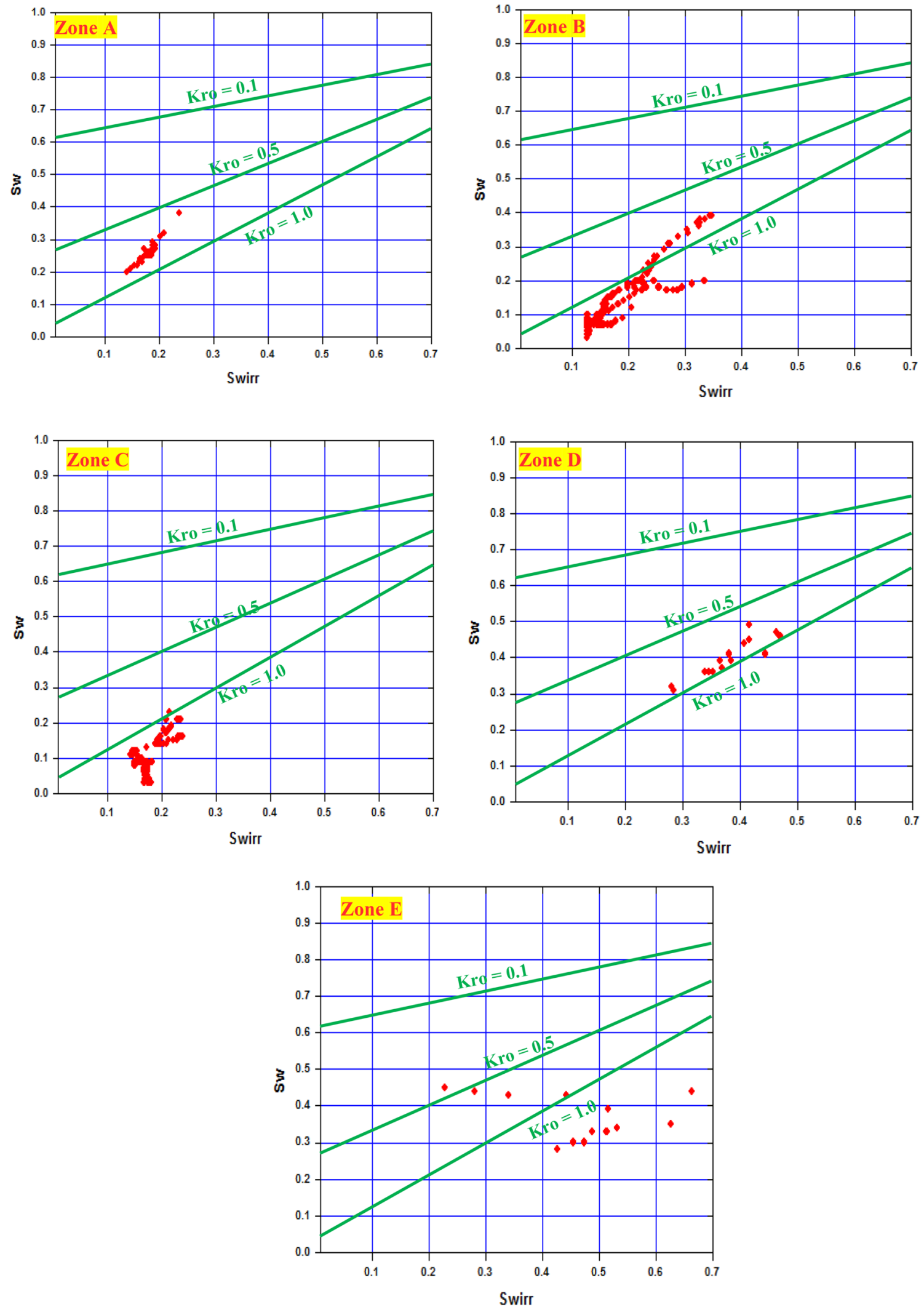

Fig. 16 Water saturation versus irreducible water saturation cross-plot (Asquith and Gibson 1982) that can be used to evaluate the relative oil permeability in the examined zones 

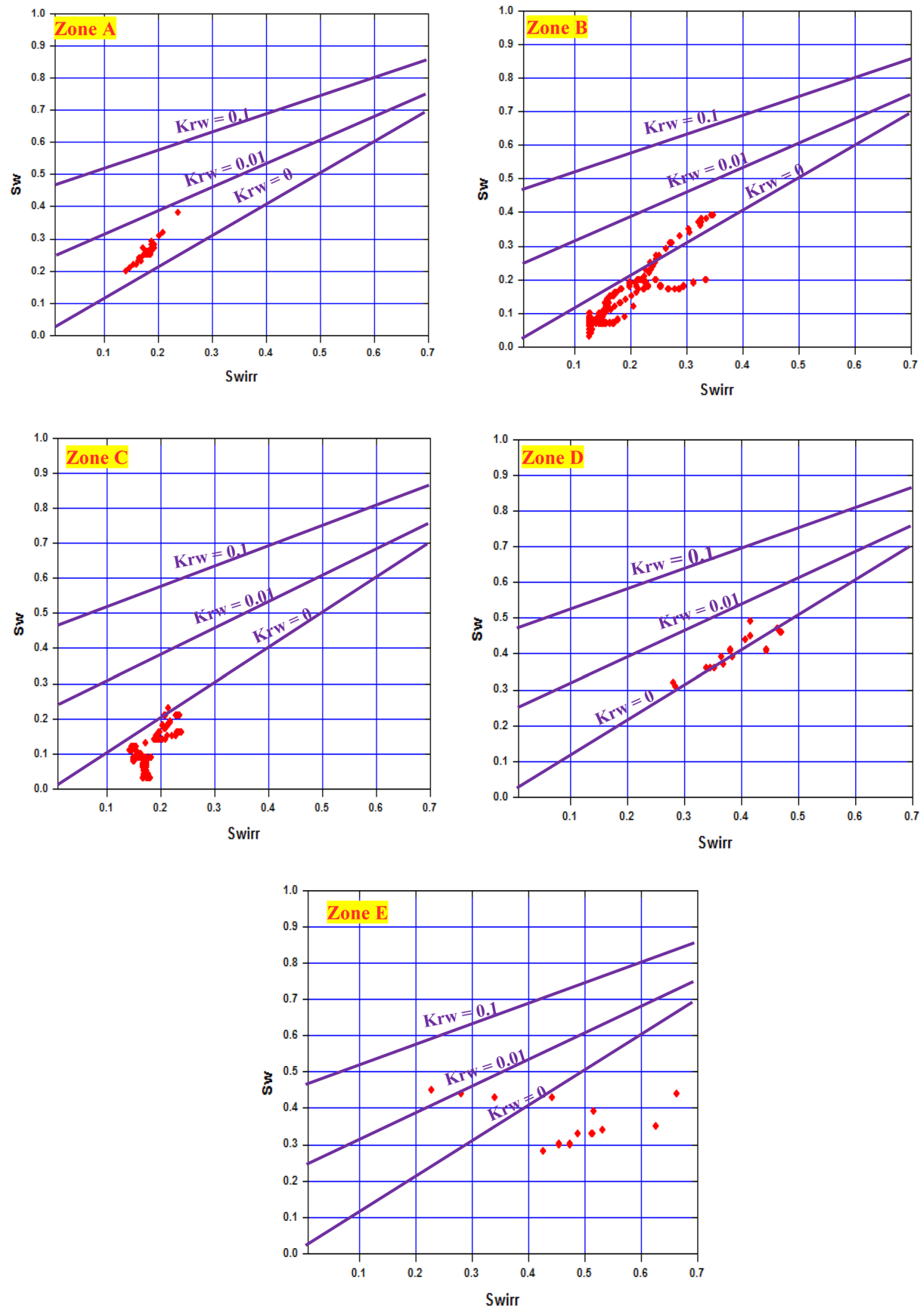

Fig. 17 Water saturation versus irreducible water saturation cross-plot (Asquith and Gibson 1982) for assessing the relative water permeability in the zones of interest 

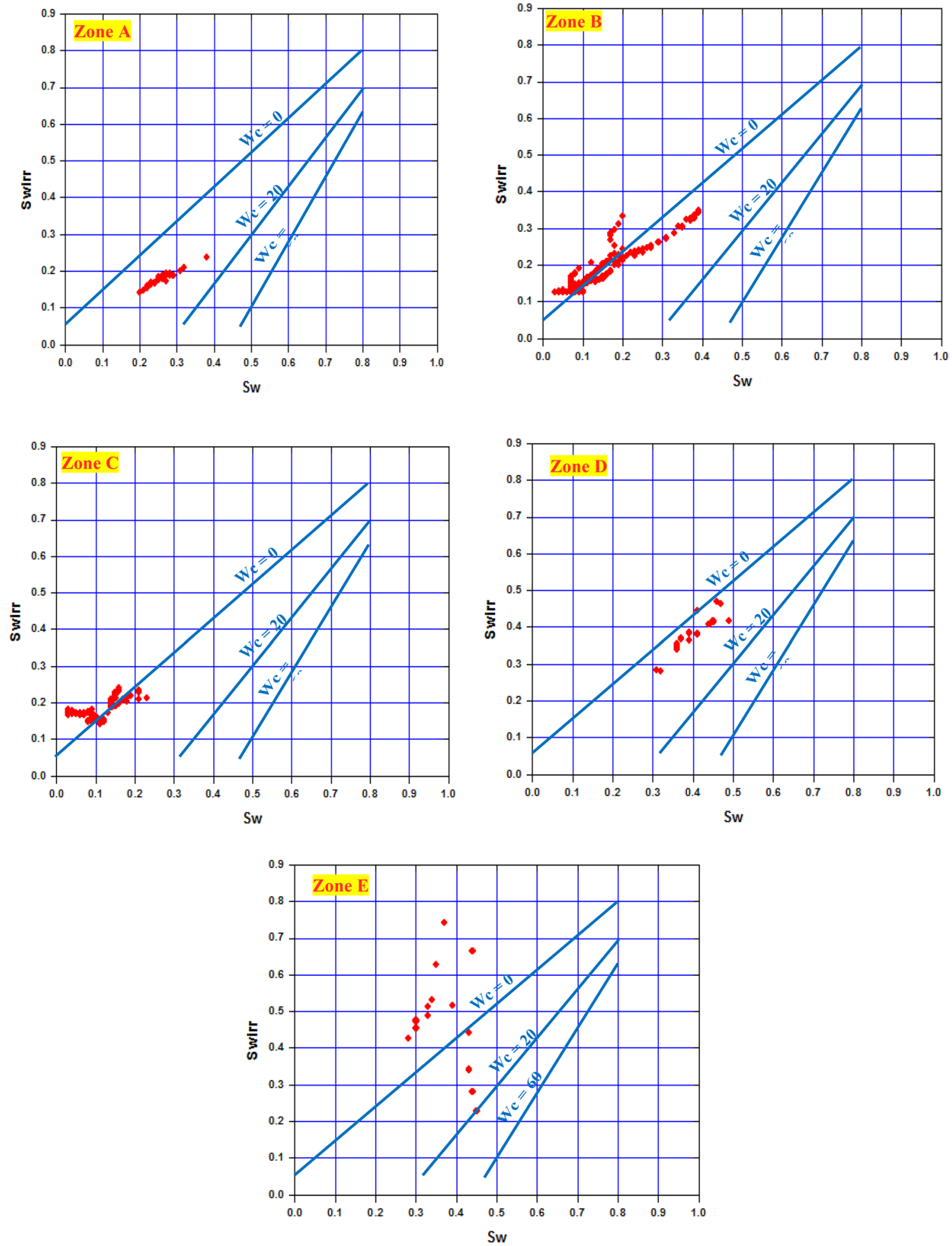

Fig. 18 Water saturation versus irreducible water saturation cross-plot (Asquith and Gibson 1982) that can be used to calculate the water-cut percentage in the zones of interest 

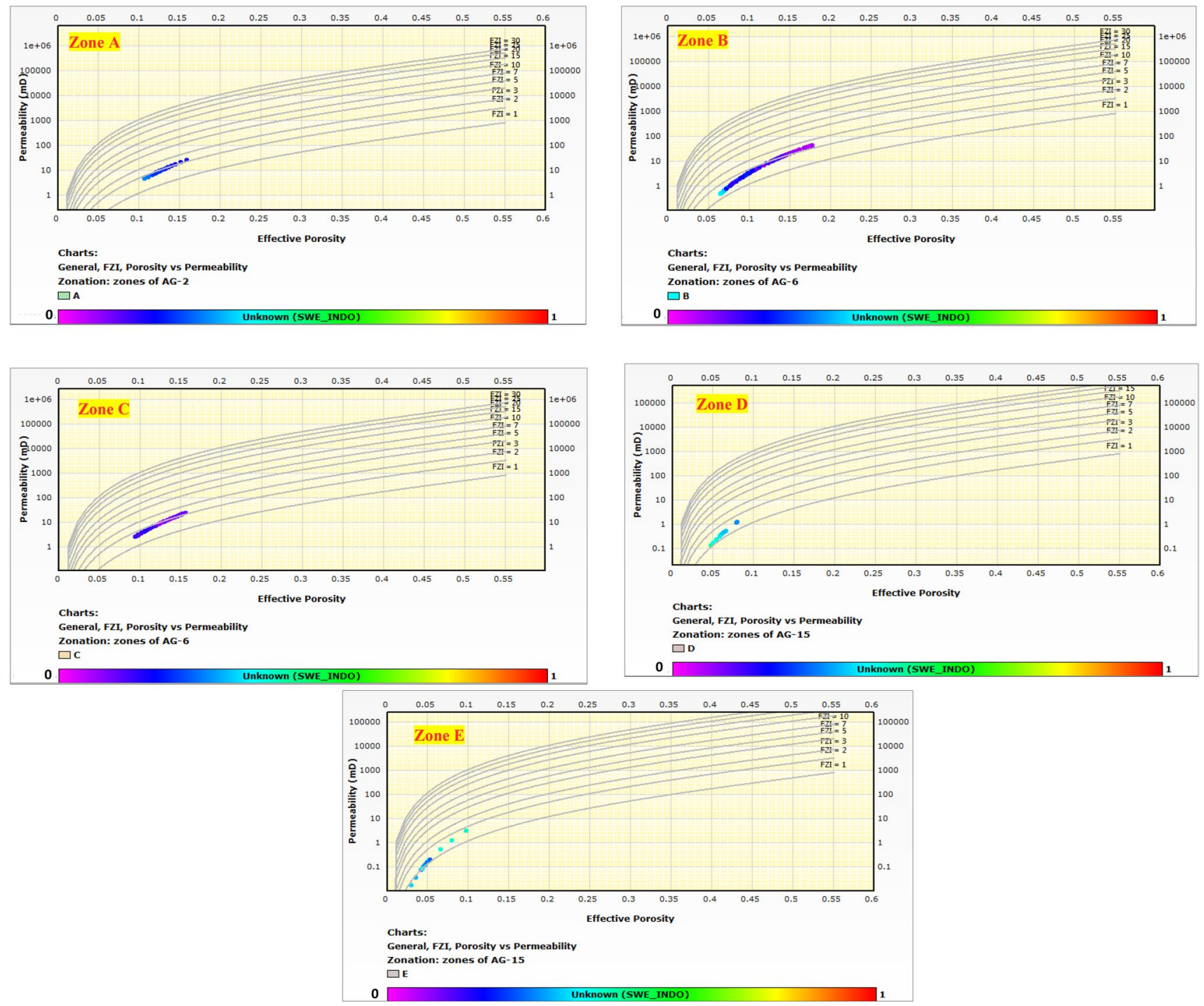

Fig. 19 Correlation chart (the y-axis represents the permeability values, $\mathrm{x}$-axis represents the effective porosity values, and the color reflects the calculated water saturation) representing the flow units (FZI) based on Amaefule et al. (1993). Note that the plotted points are not based on the microscopic measurements of rock core samples. This figure compares the characteristics of zones B and C (homogeneity and hydraulic characteristics) 

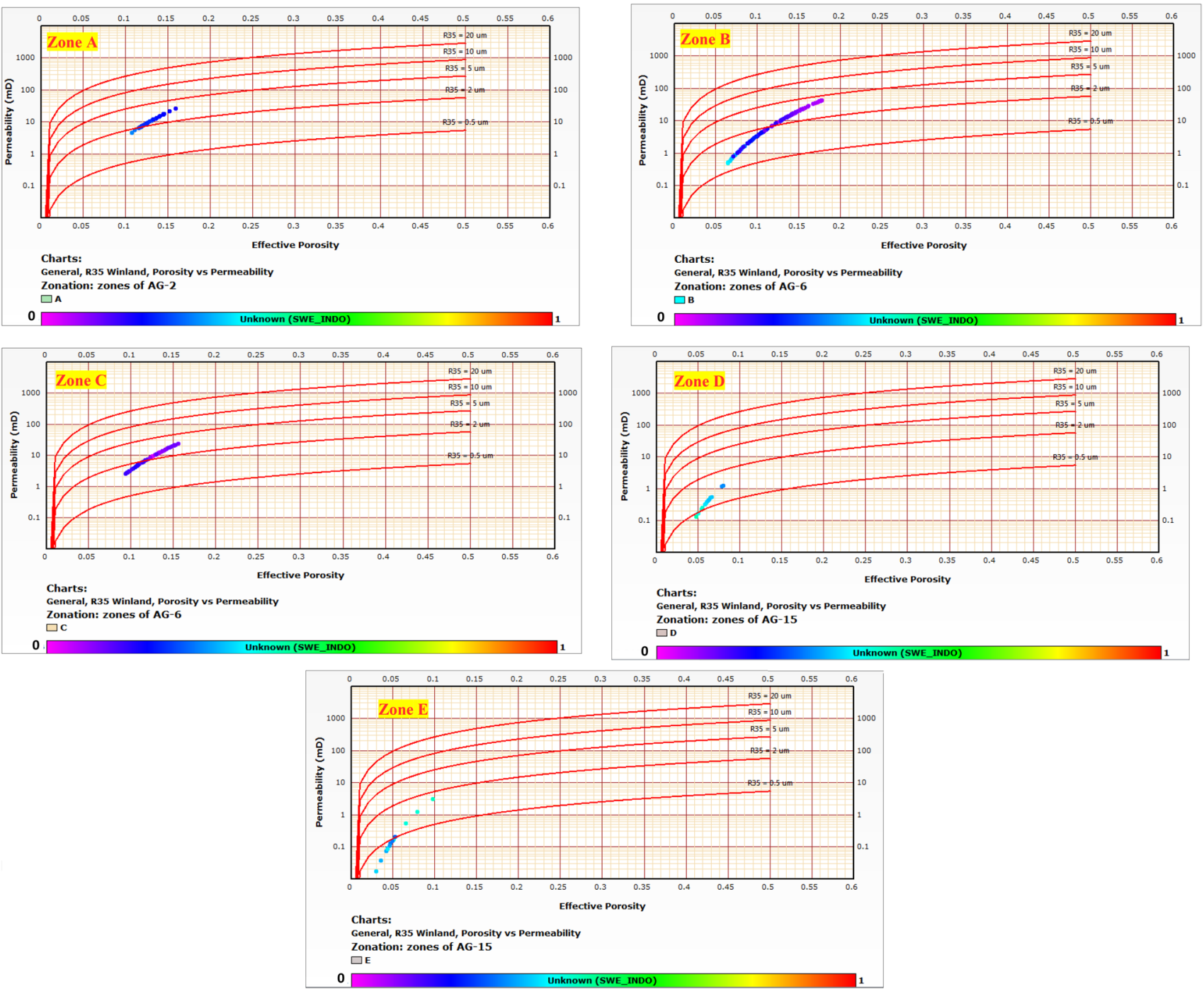

Fig. 20 Correlation graph (the $y$-axis represents the permeability values, $\mathrm{x}$-axis represents the effective porosity values, and the color reflects the calculated water saturation) indicating the $\mathrm{r} 35$ value (Winland, 1972 and 1976). Note that the plotted points are not based on the microscopic measurements of rock core samples. This figure compares the characteristics of zones $\mathrm{B}$ and $\mathrm{C}$ (homogeneity and rock quality, r35 exceeding $2 \mu$ ) 

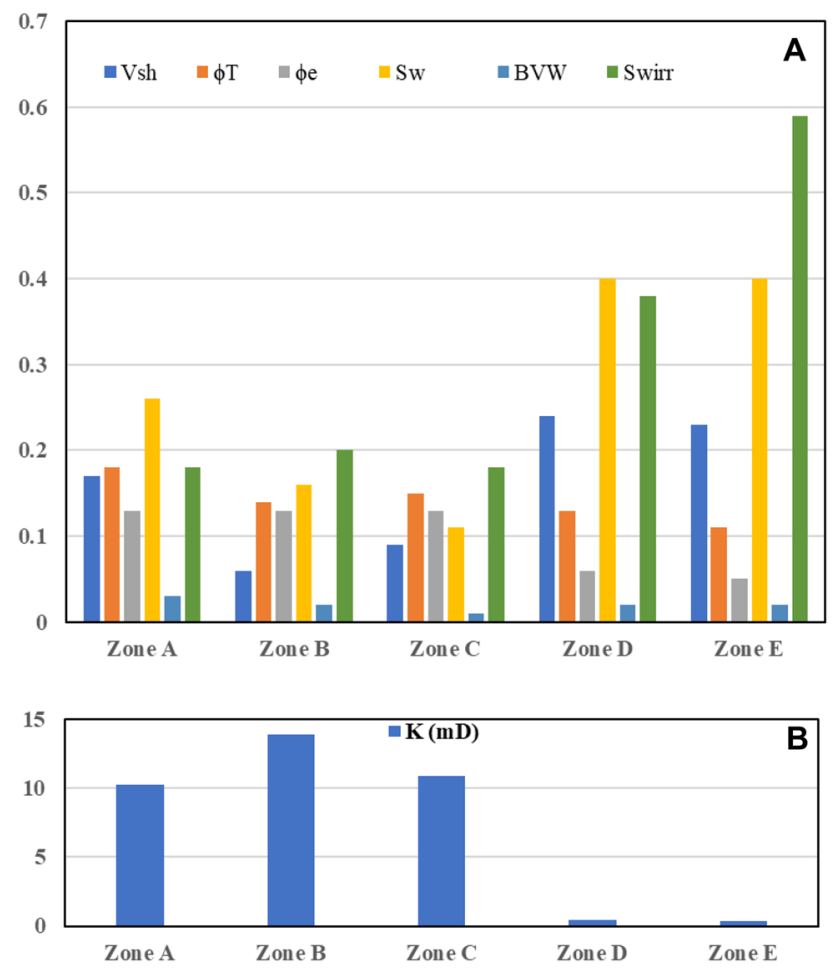

Fig. 21 a Bar graph summarizing the calculated petrophysical parameters (shale volume, total porosity, effective porosity, water saturation, bulk volume of water, and irreducible water saturation) for the promising zones. b Bar graph displays the calculated absolute permeability $(K)$ for these zones

for zones D and E in well AG-15 confirm the production of condensate with an API of 46.1, whereas zone A in well AG-2 produces gas with traces of condensate. On the other hand, the composite log of well AG-6 shows that the entire sand in zones $\mathrm{B}$ and $\mathrm{C}$ might be a hydrocarbon-bearing zone. They characterized by the presence of oil satin and display blue florescence which reflects the condensate hydrocarbons with API $>45$ (Johnson and Pile 2006). The DST data for well AG-6 are not available; therefore, DST should be carried out in zones B and $\mathrm{C}$ in this well in the future.

\section{Conclusions}

In this study, the reservoir superiority of the sandstone of the Bahariya Formation in Abu Gharadig Field, Western Desert, Egypt, was evaluated. Based on the seismic data and mapping the uppermost surface of the Bahariya Formation, the study area contains a ENE-WSW-oriented anticline, which is cut by NW-SE-trending normal faults.

The qualitative explanation of the well-log data indicates good reservoir characteristics for oil production in zone A (17 ft thick) in well AG-2, zones B ( $30 \mathrm{ft}$ thick) and C (21 ft thick) in well AG-6, and zones D (7 ft thick) and $\mathrm{E}$ (18 ft thick) in well AG-15. However, the quantitative appraisal shows that zones B and C in well AG-6 are the best intervals in terms of the reservoir performance because they exhibit the lowest shale volume, highest effective porosity, minimum water saturation, lowest BVW, and high absolute permeability (Fig. 21). They also display high relative oil permeability, low relative water permeability, and low water cut.

The crest of the mapped anticline in the topmost of Bahariya Formation in the Abu Gharadig Field is expected to be the optimum site for the installation of new exploratory wells. Accordingly, the drilling of the anticlinal crest is highly recommended including the addition of wells close to well AG-6.

The lack of important measurements that are necessary to describe the reservoir quality (e.g., $k_{\mathrm{ro}}, k_{\mathrm{rw}}$, and $W_{c}$ ) might lead to improper decisions regarding the setting of pipes considering only traditional petrophysical parameters (e.g., $\Phi, V_{\text {shale }}$, and $S_{w}$ ).

Acknowledgements I extremely appreciate the help of the Egyptian General Petroleum Corporation and Khalda Petroleum Company for providing the required geophysical data in this study. Many thanks to the Egyptian Knowledge Bank (EKB) for editing the English language of this paper by Enago services.

\section{Declarations}

Conflict of interest Here, I confirm that there is no conflict of interest.

Ethical approval Hereby, I assure that this paper has not been previously published and the manuscript reflects my own research and analysis in a truthful and complete manner.

Funding The author received no financial support for the research, authorship, and/or publication of this article.

Open Access This article is licensed under a Creative Commons Attribution 4.0 International License, which permits use, sharing, adaptation, distribution and reproduction in any medium or format, as long as you give appropriate credit to the original author(s) and the source, provide a link to the Creative Commons licence, and indicate if changes were made. The images or other third party material in this article are included in the article's Creative Commons licence, unless indicated otherwise in a credit line to the material. If material is not included in the article's Creative Commons licence and your intended use is not permitted by statutory regulation or exceeds the permitted use, you will need to obtain permission directly from the copyright holder. To view a copy of this licence, visit http://creativecommons.org/licenses/by/4.0/.

\section{References}

Abd El Aal A (1988) In structural framework of Abu Gharadig Basin Western Desert, Egypt. In: 9th Petroleum Exploration and Production Conference, Egyptian General Petroleum Corporation, Cairo. pp 20-23 
Abdelwahhab MA, Raef A (2020) Integrated reservoir and basin modeling in understanding the petroleum system and evaluating prospects: the Cenomanian reservoir, Bahariya Formation, at Falak Field, Shushan Basin, Western Desert, Egypt. J Pet Sci Eng 189:107023

Abu El Naga M (1984) In Paleozoic and Mesozoic depocenters and hydrocarbon generating areas, northern Western Desert. In: 7th Petroleum and Exploration Seminar, Egyptian General Petroleum Corporation, Cairo. vol. 8, pp 269-287

Afify AM, Sanz-Montero ME, Calvo JP, Wanas HA (2015) Diagenetic origin of ironstone crusts in the lower cenomanian bahariya formation, bahariya depression, western desert, Egypt. J Afr Earth Sci 101:333-349

Amaefule JO, Altunbay M, Tiab D, Kersey DG, Keelan DK (1993) Enhanced reservoir description: using core and log data to identify hydraulic (flow) units and predict permeability in uncored intervals/wells. SPE 26436 In: Presented at the Annual Technical Conference and Exhibition, Houston, TX, pp 3-6

Asquith G, Gibson C (1982) Basic well log analysis for geologists: methods in Exploration series. AAPG, Tulsa, Oklahoma

Awad GM (1984) Habitat of oil in Abu Gharadig and Faiyum basins, Western Desert, Egypt. AAPG Bull 68(5):564-573

El Ayouty MK (1990) Petroleum geology. In: Said R (ed) The geology of Egypt. AA Balkema, Rotterdam, pp 567-599.

Ayyad MH, Darwish M (1996) Syrian arc structures: a unifying model of inverted basins and hydrocarbon occurrences in north Egypt. In: Proc. 13th E.G.P.C. Petrol. Explor. and Prod. Conf., vol. 1, pp 40-59

Bayoumi AI, Lotfy HI (1989) Modes of structural evolution of Abu Gharadig Basin, Western Desert of Egypt as deduced from seismic data. J Afr Earth Sci (and the Middle East) 9(2):273-287

Biju-Duval B, Dercourt J, Pichon Le, x. (1977) From the tethys ocean to the mediterranean seas: a plate tectonic model of the evolution of the western Alpine system. In: Biju-Duval B, Montadert L (eds) Structural history of the mediterranean basins. Editions Technip, Paris, pp 143-164

Bosworth W, El-Hawat AS, Helgeson DE, Burke K (2008) Cyrenaican "shock absorber" and associated inversion strain shadow in the collision zone of northeast Africa. Geology 36(9):695-698

Buckles RS (1965) Correlating and averaging connate water saturation data. J Can Pet Technol 4(1):42-52

Dolson CJ, Shaan VM, Matbouly S, Harwood C, Rashed R, Hammouda $H$ (2001) The petroleum potential of Egypt. In: Downey WM, Threet CJ, Morgan AW (eds) Petroleum provinces of the twenty-first century. American Association of Petroleum Geologists (AAPG), Tulsa, pp 453-482

EGPC (1992) Western Desert, oil and gas fields, a comprehensive overview. In: 11th Petroleum Exploration and Production Conference, Egyptian General Petroleum Corporation, Cairo. pp 1-431

El Diasty WS, Moldowan JM (2012) Application of biological markers in the recognition of the geochemical characteristics of some crude oils from Abu Gharadig Basin, north Western Desert-Egypt. Mar Pet Geol 35(1):28-40

El Gazzar AM, Moustafa AR, Bentham P (2016) Structural evolution of the Abu Gharadig field area, northern Western Desert, Egypt. J Afr Earth Sci 124:340-354

El Sayed AMA, Mouse SA, Higazi A, Al-Kodsh A (1993) Reservoir characteristics of the Bahariya Formation in both Salaam and Khalda oil fields, Western Desert, Egypt. In: EGS Proc., 11Th Ann. Mtg, vol 11, pp115-132

Ela NA, Tahoun SS, Fouad T, Mousa DA, Saleh R (2018) Source rock evaluation of Kharita and Bahariya formations in some wells, North Western Desert, Egypt: visual palynofacies and organic geochemical approaches. Egypt J Pet 27(4):455-465
Elmahdy M, Tarabees E, Farag AE, Bakr A (2020) An integrated structural and stratigraphic characterization of the Apollonia carbonate reservoir, Abu El-Gharadig Basin, Western Desert Egypt. J Nat Gas Sci Eng 78:103317

Farrag GH, Baghdady A, Elnaggar OM (2021) Petrophysical attributes of the middle zone of the Bahariya Formation as a producing reservoir using core analysis correlations and $\log$ evaluation, $\mathrm{Abu}$ Sennan area, Egypt. J Afr Earth Sci 180:104225

Guiraud R, Bosworth W (1997) Senonian basin inversion and rejuvenation of rifting in Africa and Arabia: synthesis and implications to plate-scale tectonics. Rev Tectonophys 282:39-82

Johnson DE, Pile KE (2006) Well logging in nontechnical language. PennWell Books, Tulsa, p 289

Khaled KA (1999) Cretaceous source rocks at Abu Gharadig oil - and gas field, northern Western Desert, Egypt. J Pet Geol 22(4):377-395

Labib M (1985) Contributions to the geology of Upper Cretaceous with special emphasis on Turonian-Senonian sedimentation patterns and hydrocarbon potentialities in the Abu Gharadig area, north Western Desert, Egypt. Unpublished Dissertation thesis, Geology Department, Cairo University, Cairo. pp 189

Lüning S, Kolonic S, Belhadj ME, Belhadj Z, Cota L, Baric G, Wagner $T$ (2004) Integrated depostional model for the CenomanianTuronian organic-rich strat in North Africa. Rev Earth Sci Rev 64:51-117

Mansour A, Gentzis T, El Nady MM, Mostafa F, Tahoun SS (2020) Hydrocarbon potential of the Albian-early Cenomanian formations (Kharita-Bahariya) in the North Western Desert, Egypt: a review. J Petrol Sci Eng 193:107440

Moustafa AR, Khalil MH (1990) Structural characteristics and tectonic evolution of north Sinai fold belts. In: Said R (ed) The Geology of Egypt. A. A. Balkema Publishers, Rotterdam, Netherlands, pp 381-392

Moustafa AR, Badrawy RE, Gibali H (1998) Pervasive E-ENE oriented faults in Northern Egypt and their effect on the development and inversion of prolific sedimentary basins. In: Eloui M (eds.), 14th Petroleum Conference, Cairo, Egypt, The Egyptian General Petroleum Corporation. pp 51-67

Moustafa AR (2002) Structural style and timing of Syrian arc deformation in northern Egypt. Am. Assoc. Petrol. Geol. Int. Meeting (Cairo, Oct. 2002), Abstract

Moustafa AR (2008) Mesozoice Cenozoic basin evolution in the northern Western Desert of Egypt. In: Salem M, El-Arnauti A, Saleh A (Eds.), 3rd Symposium on the Sedimentary Basins of Libya, The Geology of East Libya, vol. 3, pp. 29-46

Nabawy BS, ElHariri TY (2008) Electric fabric of cretaceous clastic rocks in Abu Gharadig basin, Western Desert, Egypt. J Afr Earth Sci 52(1-2):55-61

Poupon A, Leveaux J (1971) Evaluation of water saturation in shaly formations. In: SPWLA 12th annual logging symposium. Society of Petrophysicists and Well-Log Analysts

Richardson MS, Vivian N, Cook JR, Wilkes M, Hussein H (1998) Application of fault seal analysis techniques in the Western Desert, Egypt. In: Macgregor SD, Moody JTR, Clark Lowes DD (eds) Petroleum Geology of North Africa. Geological Society of London, London, pp 297-315

Said R (1990) The geology of Egypt: Balkema. Brookfield, Rotterdam, p 734

Sarhan MA (2017a) Seismic-Wireline logs sequence stratigraphic analyses and geologic evolution for the Upper Cretaceous succession of Abu Gharadig basin, Egypt. J Afr Earth Sci 129:469-480

Sarhan MA (2017b) Wrench tectonics of Abu Gharadig Basin, Western Desert, Egypt: a structural analysis for hydrocarbon prospects. Arab J Geosci 10(18):399 
Sarhan MA (2017c) The efficiency of seismic attributes to differentiate between massive and non-massive carbonate successions for hydrocarbon exploration activity. NRIAG J Astron Geophys 6(2):311-325

Sarhan MA (2020) Possibility of intrusive igneous body beneath the Cretaceous sequence in Abu Gharadig Basin, Egypt: integration of geophysical data interpretations. Arab J Geosci 13(12):1-10

Sarhan MA, Collier REL (2018) Distinguishing rift-related from inversion-related anticlines: observations from the Abu Gharadig and Gindi Basins, Western Desert, Egypt. J Afr Earth Sci 145(2018):234-245

Sarhan MA, Basal AMK, Ibrahim IM (2017) Seismic and well-logging interpretation for evaluation of the lower Bahariya reservoir, southwest Qarun (SWQ) Field, Gindi Basin, Egypt. Mar Geophys Res 38(3):271-290

Schlumberger (1972). Log interpretation/charts. Schlumberger Well Services, Inc, Houston

Schlumberger (1984) Geology of Egypt. In: Paper presented at the Well Evaluation Conference, Schlumberger, Cairo, pp 1-64

Schlumberger (1995) In: Geology of Egypt. In: Paper presented at the Well Evaluation Conference, Schlumberger, Cairo, pp 58-66

Sestini G (1995) Egypt. In: Kulke, H. (Ed.), Regional petroleum geology of the world, part II: Africa, America, Australia and Antarctica (Vol. Beiträge zur regionalen Geologie der Erde, Gebrüder Bornträger Verlagsbuchhandlung, Stuttgart. Band 22, pp 66-87

Shahin AN (1992) In Undiscovered petroleum reserves in North Western Desert, Egypt. In: Paper presented at the 1st Int. Confer., Geology of Arab World, GUPCO, Cairo University

Shalaby MR, Hakimi MH, Abdullah WH (2011) Geochemical characteristics and hydrocarbon generation modeling of the Jurassic source rocks in the Shoushan Basin, north Western Desert, Egypt. Mar Pet Geol 28(9):1611-1624
Smith AG (1971) Alpine deformation and the oceanic areas of the Tethys, Mediterranean, and Atlantic. Geol Soc Am Bull 82(8):2039-2070

Sultan N, Abd El Halim M (1988) In Tectonic framework of Northern Western Desert, Egypt and its effect on hydrocarbon accumulations. In: Paper presented at the 8th Exploration and Production Conference, Egyptian General Petroleum Corporation, Cairo. November, pp 20-23

Wahdan M, Fahmy M, Brekelmans H (1996) 3D reservoir modelling and simulation in BAPETCO: case studies from the BED 1, 2 and 3 fields, Western Desert, Egypt. In: Proceedings 13th Petroleum Conference (Vol. 2). EGPC Cairo, pp 250-260

Wanas HA, Assal EM (2021) Provenance, tectonic setting and source area-paleoweathering of sandstones of the Bahariya Formation in the Bahariya Oasis, Egypt: an implication to paleoclimate and paleogeography of the southern Neo-Tethys region during Early Cenomanian. Sediment Geol 413:105822

Winland HD (1972) Oil accumulation in response to pore size changes, Weyburn field, Saskatchewan: amoco production company report F72-G-25, 20 p. (unpublished)

Winland HD (1976) Evaluation of gas slippage and pore aperture size in carbonate and sandstone reservoirs: amoco production company report F76-G-5, 25 p. (unpublished)

Wyllie MRJ, Rose WD (1950) Some theoretical considerations related to the quantitative evaluation of the physical characteristics of reservoir rock from electrical log data. J Petrol Technol 2(04):105-118

Publisher's Note Springer Nature remains neutral with regard to jurisdictional claims in published maps and institutional affiliations. 